$$
\begin{array}{ccccccc}
\text { L } & \text { E } & \text { T } & \text { u } & \text { v } & \text { O } & \text { s } \\
\hline \text { ARCHEOlogija } & 46
\end{array}
$$


Lietuvos istorijos institutas

\begin{tabular}{llllllll}
$\mathrm{L}$ & $\mathrm{I}$ & $\mathrm{E}$ & $\mathrm{T}$ & $\mathrm{U}$ & $\mathrm{V}$ & $\mathrm{O}$ & $\mathrm{S}$ \\
\hline
\end{tabular}

ARCHEOlogija 46 


\section{Leidybą finansavo}

\section{LIETUVOS MOKSLO TARYBA}

PAGAL VALSTYBINĘ LITUANISTINIŲ TYRIMŲ IR SKLAIDOS 2016-2024 METŲ PROGRAMĄ

(Finansavimo sutarties numeris S-LIP-19-4)

\section{Redaktorių kolegija / Editorial board:}

Atsakingoji redaktorė / Editor-in-chief dr. Agnè Čivilytė (Lietuvos istorijos institutas, Vilnius / Lithuanian Institute of History, Vilnius)

Atsakingosios redaktorès pavaduotoja / Assistant Editor dr. Elena Pranckènaitè (Lietuvos istorijos institutas, Vilnius / Lithuanian Institute of History, Vilnius)

Dr. Laurynas Kurila (Lietuvos istorijos institutas, Vilnius / Lithuanian Institute of History, Vilnius)

Dr. Valdis Bērziņš (Latvijos universitetas, Latvijos istorijos institutas, Ryga / University of Latvia, Institute of Latvian History, Riga)

Habil. dr. Anna Bitner-Wróblewska (Valstybinis archeologijos muziejus Varšuvoje, Lenkija / State Archaeological Museum in Warsaw, Poland)

Dr. Christoph Jahn (Baltijos ir Skandinavijos archeologijos centras, Šlèzvigas, Vokietija / Center for Baltic and Scandinavian Archaeology, Schleswig, Germany)

Prof. dr. Rimantas Jankauskas (Vilniaus universitetas, Lietuva / Vilnius University, Lithuania)

Akad. prof. dr. Eugenijus Jovaiša (Lietuvos mokslu akademija, Vilnius / Lithuanian Academy of Sciences, Vilnius)

Habil. dr. Bartosz Kontny (Varšuvos universitetas, Archeologijos fakultetas, Lenkija / Faculty of Archaeology, University of Warsaw, Poland)

Prof. dr. Valter Lang (Tartu universitetas, Estija / University of Tartu, Estonia)

Doc. dr. Algimantas Merkevičius (Vilniaus universitetas, Lietuva / Vilnius University, Lithuania)

Habil. dr. Tomasz Nowakiewicz (Varšuvos universitetas, Archeologijos fakultetas, Lenkija / Faculty of Archaeology, University of Warsaw, Poland)
Habil. dr. Grzegorz Osipowicz (Mikalojaus Koperniko universitetas, Torunè, Lenkija / Nicolaus Copernicus University, Toruń, Poland)

Dr. Gytis Piličiauskas (Lietuvos istorijos institutas, Vilnius / Lithuanian Institute of History, Vilnius)

Dr. Eve Rannamäe (Tartu universtitetas, Estija / University of Tartu, Estonia)

Dr. Andra Simniškyte (Lietuvos istorijos institutas, Vilnius / Lithuanian Institute of History, Vilnius)

Dr. Roberts Spirgis (Latvijos universitetas, Latvijos istorijos institutas, Ryga / University of Latvia, Institute of Latvian History, Riga)

Dr. Eugenijus Svetikas (Lietuvos istorijos institutas, Vilnius / Lithuanian Institute of History, Vilnius)

Dr. Andris Šnē (Latvijos universitetas, Ryga / University of Latvia, Riga)

Doc. dr. Gintautas Zabiela (Klaipédos universitetas, Lietuva / Klaipeda University, Lithuania)

Prof. dr. Šarūnas Milišauskas (Niujorko valstijos Bafalo universitetas, JAV / New York State University at Buffalo, USA)

Prof. dr. Timothy Chevral (Niujorko valstijos Bafalo universitetas, JAV / New York State University at Buffalo, USA)

Prof. dr. Johan Ling (Gioteborgo universitetas, Švedija / University of Gothenburg, Sweden)

Sekretorè / Secretary Dovilè Urbonavičiūtè-Jankauskienė

Redakcijos adresas / Editorial Board address:

Lietuvos istorijos institutas, Archeologijos skyrius

Kražių g. 5, LT-01108 Vilnius

Tel. (+370) 5 2614935, fax (+370) 52611433

e-mail: lietuvosarcheologija@gmail.com;

civilytea@gmail.com

\section{Žurnalas registruotas: EBSCO Publishing: Central and Eastern European Academic Source European Reference Index for the Humanities and Social Sciences (ERIH PLUS)}




\section{TURINYS / CONTENT}

Agnè Čivilytè

Agnè Čivilytè

Jonas Beran

Gabrielè Gudaitienè

Andreas Kotula, Henny Piezonka, Thomas Terberger

Vygandas Juodagalvis

Eglè Šatavičè

Grzegorz Osipowicz, Justyna Orłowska, Gytis Piličiauskas, Giedrẻ Piličiauskienė, Mariusz Bosiak

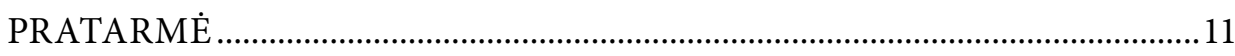

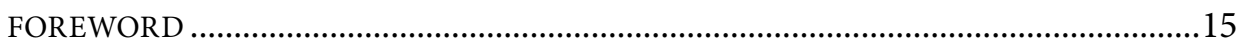

RUDENS POPIETĖ SU RIMUTE RIMANTIENE _.............................................19

AUTUMN AFTERNOON WITH RIMUTE் RIMANTIENĖ

GREETINGS FROM OLD CENTRAL-EASTERN GERMANY:

MEMORIES OF INTERESTING TIMES .27

LINKĖJIMAI IŠ PIETRYČIŲ VOKIETIJOS: PRISIMINIMAI APIE ĮDOMIUS LAIKUS

\section{STRAIPSNIAI / ARTICLES}

EIGULIAI, ONE OF RIMUTE் RIMANTIENĖ'S FIRST EXCAVATIONS A REVISED INTERPRETATION .33

EIGULIAI - VIENA PIRMŲJŲ RIMUTĖS RIMANTIENĖS KASINĖJIMŲ VIETŲ.

NAUJA INTERPRETACIJA

THE MESOLITHIC CEMETERY OF GROß FREDENWALDE (NORTH-EASTERN GERMANY) AND ITS CULTURAL AFFILIATIONS.......65 GROS FREDENVALDE (ŠIAURĖS RYTŲ VOKIETIJA) MEZOLITO LAIKOTARPIO KAPINYNAS IR JO KULTÜRINĖS SĄSAJOS .83

AKMENINIAI GLUDINTI KIRVIAI LIETUVOJE. TIPOLOGIJOS IR TERMINOLOGIJOS PROBLEMOS .85 GROUND STONE AXES IN LITHUANIA. PROBLEMS OF TYPOLOGY AND TERMINOLOGY 108

NEOLITHIC SOCIETIES AND THEIR POTTERY IN SOUTH-EASTERN LITHUANIA 111 NEOLITO BENDRUOMENĖS IR JỤ KERAMIKA PIETRYČIỤ LIETUVOJE. 142

OSSEOUS POINTS AND HARPOON HEADS FROM ŠVENTOJI SUBNEOLITHIC SITES, COASTAL LITHUANIA. FIRST TRACEOLOGICAL INSIGHT INTO THE WAY THEY WERE PRODUCED AND USED 147

KAULINIAI ANTGALIAI IR ŽEBERKLAI LIETUVOS PAJÜRIO ŠVENTOSIOS SUBNEOLITINĖSE GYVENVIETĖSE: GAMYBA IR NAUDOJIMAS PIRMU巳JŲ TRASOLOGINIŲ TYRIMỤ DUOMENIMIS 168 
Sławomir Kadrow

Frédéric Surmely

Rokas Vengalis, Jonas Volungevičius, Gintautas Vèlius, Albinas Kuncevičius, Justina Poškienè, Regina Prapiestienè

Andra Simniškytè

Inga Merkyte்

Rokas Vengalis
MACRO AND MICRO SCALE NEOLITHISATION PROCESSES IN SOUTH-EASTERN POLAND AGAINST THE BACKGROUND OF CENTRAL-EASTERN EUROPE 171

PIETRYČIŲ LENKIJOS NEOLITIZACIJOS PROCESAI MIKRO- IR MAKROLYGMENIMIS VIDURIO IR RYTŲ EUROPOS KONTEKSTE 187

CHARACTERIZATION OF TERTIARY FLINTS BY GEOCHEMISTRY: APPLICATION TO THE FRENCH TERRITORY.

TERCIARO TITNAGO PRANCÜZIJOS TERITORIJOJE CHARAKTERIZAVIMAS NAUDOJANT GEOCHEMINI METODĄ

ŽMOGUS PRIEŠ GAMTĄ: RELJEFO TRANSFORMAVIMAS İRENGIANT XIII-XIV A. KERNAVÉS PILI IR JO SUKELTI EROZINIAI PROCESAI ....... 207 MAN AGAINST NATURE: THE TRANSFORMATION OF THE RELIEF DURING THE CONSTRUCTION OF KERNAVĖ CASTLE IN THE $13^{\mathrm{TH}}-14^{\mathrm{TH}}$ CENTURIES AND THE EROSIONAL PROCESSES IT CREATED 248

KUPIŠKIO (AUKŠTUPĖNŲ) PILIAKALNIS: TEORINĖS PRIELAIDOS

IR TYRIMŲ REZULTATAI .255

HILLFORT OF KUPIŠKIS (AUKŠTUPĖNAI): THEORETICAL ASSUMPTIONS AND INVESTIGATION RESULTS 284

\section{KITAIP APIE ARCHEOLOGIJA /} ALTERNATIVE PERCEPTIONS OF ARCHAEOLOGY

Šarūnas Radvilavičius

KELIAUTOJO LAIKU UŽRAŠAI. 289

THE NOTEBOOK OF TIME TRAVELLER

\section{DISKUSIJOS / DISCUSSIONS}

STUDIES OF ANCIENT DNA. THE RACE FOR THE ULTIMATE ANSWER .293

SENOVĖS DNR TYRIMAI: KARŠTLIGIŠKOS ATSAKYMŲ PAIEŠKOS

\section{RECENZIJOS / REVIEWS}

ALGIMANTAS MERKEVIČIUS (SUD.), 2018. ANKSTYVOJO METALŲ LAIKOTARPIO GYVENVIETÉS LIETUVOJE (SETTLEMENTS OF EARLY METAL PERIOD IN LITHUANIA). 305

INFORMACIJA APIE PROJEKTUS / INFORMATION ABOUT THE PROJECTS 309

AUTORIŲ DĖMESIUI. 327 GUIDELINES FOR AUTHORS 


\title{
KUPIŠKIO (AUKŠTUPĖNŲ) PILIAKALNIS: TEORINĖS PRIELAIDOS IR TYRIMŲ REZULTATAI
}

\author{
ANDRA SIMNIŠKYTÉ
}

Lietuvos istorijos institutas, Archeologijos skyrius, Kražių g. 5, 01008, Vilnius, el. paštas: andrasimnas@gmail.com

Lig šiol buvęs netyrinètas Kupiškio (Aukštupènu) piliakalnis daugelio tyrinètoju laikomas nuo kryžiuočiu puolimo gynusios pilies vieta. 2017-2018 m. piliakalnyje buvo atlikti tarpdisciplininiai tyrimai: ištirtas $20 \mathrm{~m}^{2}$ plotas, padaryta 150 gręžinių, atlikti geofizikiniai aikštelès matavimai, laboratoriniai grunto ir archeologinès medžiagos méginių tyrimai. Rezultatai iš esmès atitiko teorinị Sèlos krašto piliakalniu raidos modeli, kartu pateike gana netikètų duomenų apie piliakalnị. Prieš apgyvenima kalva buvo visiškai kitokios formos, nei matoma dabar. Archeologiniai tyrinejimai patvirtino geocheminiu grunto tyrimu pagrindu iškeltą prielaidą, jog kalva apgyventa dar I tūkstantm. pr. Kr. Aikšsteles pakraščiuose VIII-V a. pr. Kr. suręsta akmenu, grunto, medžio konstrukcija per ta laika bent kelis kartus dege ir vèl buvo atstatyta. Radiniai rodo, kad piliakalnyje gyventa ir erų sandūroje, tačiau to meto kultūrinio sluoksnio ar ịtvirtinimu neaptikta. I tūkstantm. po Kr. piliakalnis galejo tarnauti atsiradus pavojui, ugnis jo ịtvirtinimus naikino V-VI a. ir VIII-X a. Vèlesniu laiku pédsaku neaptikta.

Reikšminiai žodžiai: Kupiškis (Aukštupènai), piliakalnis, apgyvenimas, tarpdisciplininiai tyrimai.

The hillfort of Kupiškis (Aukštupenai) has never been investigated before but was regarded by many researchers as a former location of a wooden castle, used for defence during the attacks of the Teutonic Order. Between the years 2017 and 2018, interdisciplinary investigations were conducted on the hillfort, which included excavations of a $20 \mathrm{~m}^{2}$ area, a geophysical survey, a survey and soil sampling from 150 drilled boreholes, and laboratory analysis of soil samples and archaeological material. Although the obtained results corresponded with the theoretical model of Selonian hillforts, new and unexpected details about the structure of the hillfort were also revealed. Prior to the establishment of settlement structures, the hill was of a completely different shape than it is now. Archaeological excavation confirmed the assumption based on soil geochemical analysis that the hill was settled during the 1st millennium BC. A structure of stones, soil and wood, was built along the edges of the hilltop during the period between the 8th and 5 th centuries $B C$, during which it burned on several occasions and was rebuilt. Finds from the hillfort attest to the fact that people lived here during the turn of the millennium. However, no cultural layer or fortification features of this period have been detected. During the 1st millennium AD, the hillfort could have been used during emergencies. Hillfort reinforcements were destroyed by fire during the 5th-6th century and the 8th-10th century. Lastly, no traces of activity on the hillfort were detected for later periods.

Key words: Kupiškis (Aukštupènai), hillfort, settlement, interdisciplinary research.

\section{IVADAS}

Piliakalniai - vieni išraiškingiausių ir kraštovaizdyje labiausiai išsiskiriančių archeologinių objektų. Iš dalies tai lèmè jų ištirtumo lygmenị, palyginti su kitos rūšies objektais, pvz., gyvenvietemis. Piliakalnių raida ne kartą buvo aptarta ir archeologų darbuose tiek visos Lietuvos mastu, tiek atskirais regionais (Tarasenka 1956; Kulikauskas 1982; Luchtanas 1992; Zabiela 1995; 2003; 2005; Vengalis 2009; Vitkūnas, Zabiela 2017; Užgalis 2018). Šio straipsnio centre - istoriniame Sèlos regione esančio Kupiškio (Aukštupėnų) piliakalnio tyrimų rezultatai. 
Piliakalnis lig šiol buvęs netyrinètas, tad, 2017 paskelbus Piliakalnių metais, Kupiškio miesto savivaldybè èmèsi iniciatyvos piliakalnị nagrinèti moksliniais tikslais. Buvo siekiama kuo daugiau informacijos surinkti neinvaziniais ir mažai invaziniais būdais. Tyrimai vyko keliais etapais: $2017 \mathrm{~m}$. buvo atlikti geoarcheologiniai ir geofizikiniai žvalgymai (I etapas), o 2018 m. - archeologiniai kasinejjimai (II etapas). Šie darbai pradèti su tam tikromis prielaidomis apie piliakalnị ir galimą jo raidą bei reikšmę. Teorinių prielaidų pagrindas - medžiagos apie kultūrinę Sèlos regiono raidą apibendrinimas (Simniškytė 2013), lèmęs ir preliminarios Sèlos piliakalnių raidos modelį. Atskira šio modelio dalis - hipotezė apie galbūt reikšmingą piliakalnio vaidmenị II tūkstantm. po Kr. pradžioje bei medinę pilị, įrengtą gintis nuo kryžiuočių. Dar viena prielaida atsirado baigus pirmą tyrimų etapą ir nustačius fosforo $(P)$ pagausèjimą apatinèje antropogeninių sedimentų dalyje: tai rodo kalvoje buvus I tūkstantm. pr. Kr. gyvenvietės horizontą, nors ị ankstyvuosius piliakalnius šis piliakalnis išoriškai nepanašus.

Šio straipsnio tikslas - pristatyti 2017-2018 m. tarpdisciplininių tyrimų rezultatus ir įvertinti, kaip jie atitinka ịvardytas prielaidas.

\section{PILIAKALNIO PADE்TIS, ŽINIOS APIE JI}

Piliakalnis yra istorinèje Sèlos žemèje, Kupiškio miesto Š pakraštyje (1 pav.). Objektas žinomas ir Kultūros vertybių registre registruotas (u. k. 23819) dviem vardais: Kupiškio ir Aukštupènų. Didžioji teritorijos ir vizualinès apsaugos zonos dalis yra administracinėse Kupiškio miesto ribose, šiaurinė ir rytinè dalys - Aukštupènų kaime. Piliakalnis stūkso netoli geomorfologinės ribos tarp Vidurio ir Šiaurès Lietuvos žemumų srities Nevėžio moreninès lygumos bei i R-PR plytinčios moreninès fluvioglacialinès Aukštaičių plynaukštès. Ledyno tirpsmo vandenų srautai sudare erozini paslènio kyšulị, kuriame ir yra piliakalnio kalva kairiame Lèvens krante, 1980-1984 m. suformuotų Kupiškio marių P gale. Iš Š jị supa Aukštupio upelis, iš V - Lèvens slènis, iš R - užpelkèjusios daubos, $\mathrm{P}$ kalva siekiasi su gretima aukštuma. Piliakalnio aikštelè $40 \times 110 \mathrm{~m}$ dydžio, 8-20 m aukščio. Š, R ir P šlaituose $4 \mathrm{~m}$ žemiau aikštelès krašto supiltą $280 \mathrm{~m}$ ilgio, 1,8 $\mathrm{m}$ aukščio ir $7 \mathrm{~m}$ pločio pylimą (V šlaite jo vietoje išlikusi tik terasa) nuo aikštelès skiria 3-4 m pločio, $2 \mathrm{~m}$ gylio griovys (2-3 pav.). Piliakalnio papèdeje esama neittvirtintos gyvenvietès (Baubonis, Zabiela 2005, p. 472-475).

Kalva kurị laiką naudota ūkinèms reikmėms, buvo ariama ir ganoma. Pirmojo pasaulinio karo metais piliakalnyje įrengtų apkasų vietos tebėra žymios ir dabar. 1924 m. piliakalnis atiteko Lietuvai pagražinti draugijos Kupiškio skyriaus valdybai, tad ji piliakalnị prižiūrèjo, net apjuosė spygliuota viela. Esama duomenų, jog tada jis buvo nemokšiškai nulygintas, aikštelèje padaryti takeliai, ji apsodinta medeliais (VAK, f. 1, ap. 1, b. 54; Paulauskas 1979, p. 16), ir sovietmečiu piliakalnị jie buvo visiškai užgožę.

Su piliakalniu siejama daug legendų. Pasakojama apie jame nugrimzdusią bažnyčią, kad piliakalnị švedai kepurèmis supylè. Bet plačiausiai žinomos legendos apie brolius milžinus Aukštupènų ir Paketurių kaimų kalvose: tai jie pypkiuodami piliakalnị ir supylè. Beje, Aukštupènų kalnas esantis vieno brolio milžino kapas (Krzywicki 1906, p. 16, 18, 23; Matulionis 1921; Elisonas 1925, p. 449-450; Vaitkevičius, Vaitkevičienè 2011; Totorytè-Pustovaitienè 2018, p. 24-27).

Archeologinès informacijos apie piliakalnị esama jau XIX a. viduryje. Dažniausiai apsiribota ịtvirtinimų buvimo faktu ar trumpu išvaizdos aprašymu (Baliński, Lipiński 1846, p. 282; Гуковский 1890, p. 5354; Valanczauskas 1891, p. 47; Покровский 1899, p. 63; Tarasenka 1928, p. 98 (Aukštupènai), p. 163 (Kupiškis); Matulionis 1921; Elisonas 1925, p. 438). Piliakalnị lankęs ir su vietiniais senoliais bendravęs Ludwikas Krzywickis mini, jog dar 1830 m. kalva nebuvo apaugusi žole, tarsi ją neseniai kas būtų kasęs, o piliakalnis - sąlygiškai nesenų laikų objektas 


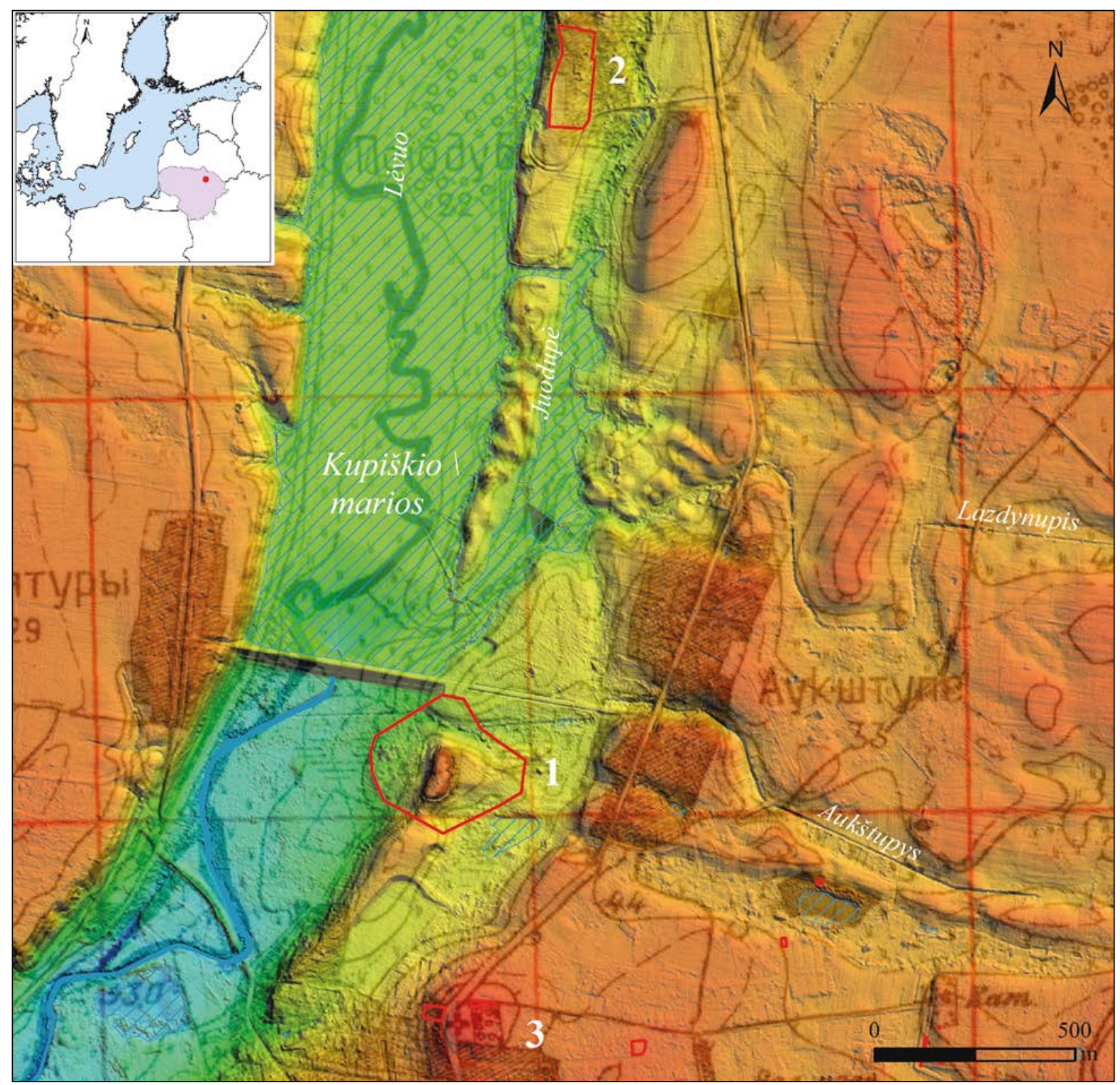

1 pav. Kupiškio (Aukštupėnų) piliakalnio (1), Kupiškio (Pajuodupès) dvarvietės (2) ir Kupiškio miesto (3) situacija. Kartografinis pagrindas - reljefo modelis pagal LIDAR duomenis ir pagal instrumentinę topografinę 1882-1907 m. carinès Rusijos nuotrauką (M 1:21 000) kaizerinės Vokietijos išleistas karinis topografinis žemèlapis (M 1:25 000). A. Simniškytès brèž.

(Krzywicki 1906, p. 16, 23; Крживицкий 1909, p. 89, 92-93). Dabar jau sunku atsekti, kas pirmas ir kuo remdamasis spejo Kupiškio piliakalnio vietoje XIII a. galèjus būti pilị, lietuvius gynusią nuo kryžiuočių. Didžiausią ìspūdị darè vèliausiai naudoto piliakalnio vaizdas. Kronikose pilis neminima dèl to, kad ordino kariuomenè ją sugriovė jau per pirmus žygius antrame
XIII a. ketvirtyje, kronikininkams dar nespejjus apie ją sužinoti (Nezabitauskas 1964, p. 3; 1968, p. 3; Kviklys 1965, p. 623; Paulauskas 1979, p. 17).

I Š nuo piliakalnio $2009 \mathrm{~m}$. buvo iškasta $2 \times$ $5 \mathrm{~m}$ dydžio perkasa, aptikta maišyto grunto be archeologinių pėdsakų, palikto $1984 \mathrm{~m}$. statant Lèvens užtvanką (Petrulienè 2009). Iš piliakalnio ar 


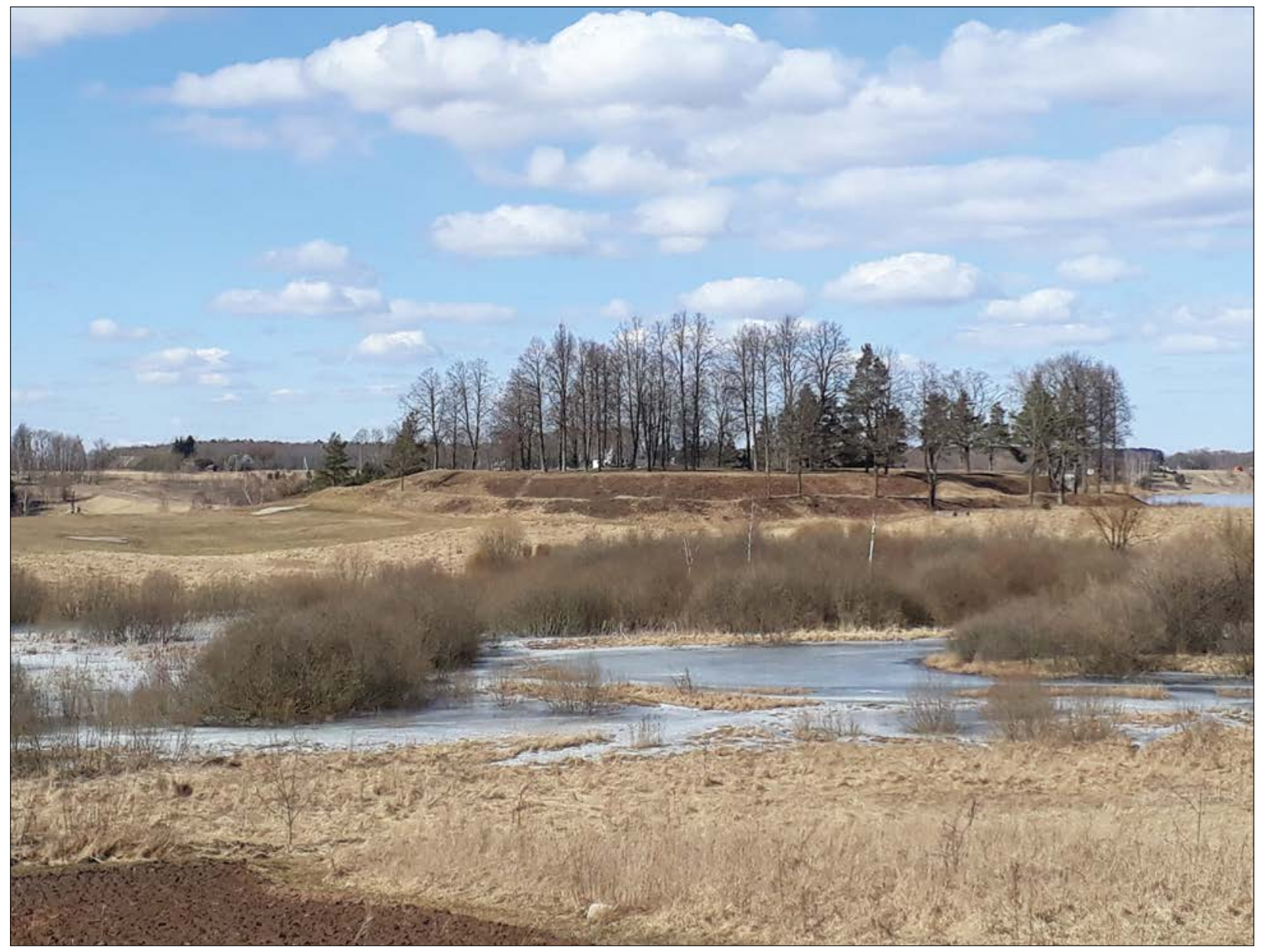

2 pav. Kupiškio (Aukštupènų) piliakalnis iš R, 2018 m. A. Simniškytès nuotr.

3 pav. Kupiškio (Aukštupènų) piliakalnio planas ir pylimų pjūviai (Кживицкий 1909, puc. 8)

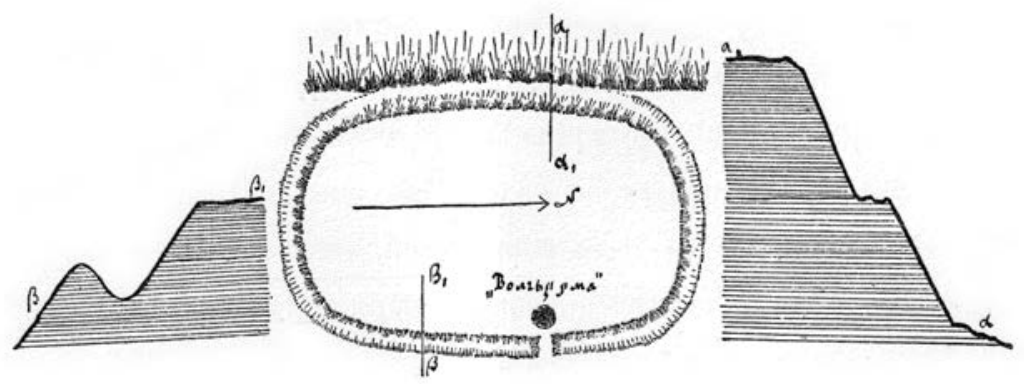

jo papėdės kelios lipdytinės keramikos šukès lygiu ir grublètu paviršiumi saugomos Lietuvos nacionaliniame muziejuje. Su piliakalniu siejamas $10,6 \mathrm{~cm}$ ilgio akmeninis kirvelis keturkampe pentimi, rastas Kupos vagoje už $1 \mathrm{~km}$ nuo piliakalnio (Zabiela 2016, p. 124-126). Pagal šiuos fragmentiškus duomenis ir dabartinị vaizdą piliakalnis datuojamas I tūkstantm. po Kr. - II tūkstantm. po Kr. pradžia (LAA 1975, p. 90 (nr. 352); Daugudis, Tebelškis 1997, p. 24; Baubonis, Zabiela 2005, p. 472-475; Simniškytè 2013, p. 262). 


\section{SĖLOS PILIAKALNIŲ RAIDOS MODELIS IR KUPIŠKIO PILIAKALNIS}

Sèlos piliakalnių tyrinèta nedaug, didelio masto kasinejjimai, vykdyti tik XX a. pradžioje, rèmėsi tame laikotarpyje būdinga metodika, akcentuojant radinius, o ne jų paplitimą ar stratigrafiją. Dėmesys radiniams išliko ir vèliau. Nemažą informacijos dalị sudaro ne kasinejjimų metu surinktų radinių kolekcijos. Vadovaujantis sukaupta informacija ir buvo rekonstruota kultūrinè Sèlos krašto raida priešistoriniais laikais bei piliakalnių raidos modelis joje (Simniškytė 2005; 2013). Vèliau lietuviškoje Sèlos dalyje kiek plačiau tyrinètas tik Moškènų (Laukupėnų) piliakalnis (Kavaliauskas 2014), tad modelio tinkamumui ịvertinti turèta nedaug naujų duomenų.

Sèlos piliakalnių raidoje galima išskirti kelis etapus, iš esmès atitinkančius bendrąsias tendencijas Lietuvoje, tačiau turinčius vietinių bruožų:

- Brūkšniuotosios keramikos kultūros laikotarpyje, maždaug nuo II/I tūkstantm. pr. Kr. sandūros iki pirmųjų amžių po Kr., kalvose kurtos prasčiau ar geriau ịtvirtintos gyvenvietès - ankstyvieji piliakalniai.

- Mūsų eros pradžioje ankstyvieji piliakalniai buvo apleidžiami, gyvenvietės kūrèsi atokiau jų. Pavieniai vėlyvojo romėniškojo periodo dirbiniai rodo, jog piliakalniai, greičiausiai, lankyti, tačiau nuolat juose negyventa.

- I tūkstantm. viduryje - antroje puseje piliakalnių paskirtis keitèsi. Juos tvirtino, atnaujino gynybinius ịtvirtinimus, tačiau kultūrinio sluoksnio pėdsakų aikštelèse nèra arba jis labai nežymus. Žmonių veiklos pėdsakai sutelkti papèdèse.

- II tūkstantm. po Kr. pradžioje žmonių veikla telkèsi taip pat papèdèse, to meto pèdsakų nustatyta tik kelių piliakalnių aikštelèse. Tarp radinių pasitaikè susijusių su mainais bei prekyba, todèl manytina, kad tokie piliakalnių ir gyvenviečių kompleksai galèjo būti svarbūs teritoriniai židiniai. Visi tokie objektai tyrinèti šiaurinèje Sèlos dalyje - Latvijos teritorijoje.

- XII a. Sèlos piliakalniai sunyko. Nors karinių susirèmimų pėdsakų nenustatyta, chronologiškai etapas sutampa su bundančiu artimiausių kaimynų - lietuvių - valstybingumu. Prie apleistų piliakalnių jau negrịžo, XV-XVI a. dvarai, miesteliai kūrèsi atokiau. Padauguvio padètis kiek kitokia: čia naujų centrų nevengta kurti senųjų - priešistorinių piliakalnių - vietose; XIV a. buvo pastatytos mūrinès Sèlpilio, Altenès pilys.

Svarstant Kupiškio piliakalnio chronologiją ir galimą svarbą kraštą apgyvenant, lig šiol buvo galima remtis netiesioginiais duomenimis, pirmiausia - dabartiniu jo vaizdu, kuris gerokai skiriasi nuo kitų I tūkstantm. pr. Kr. - I tūkstantm. po Kr. regiono piliakalnių. Tai - vienas didžiausių piliakalniu vadinamų objektų Sẻlos krašte. Maždaug 4400 $\mathrm{m}^{2}$ aikštelëje yra priešistoriniams laikams nebūdingi ịtvirtinimai: net $280 \mathrm{~m}$ ilgio žiedinis pylimas su gynybiniu grioviu. Už $3 \mathrm{~km}$ nuo piliakalnio, Pyragiuose, $1898 \mathrm{~m}$. rastos palaidojimo su X-XII a. papuošalais liekanos patvirtina, jog Kupiškio apylinkèse II tūkstantm. pradžioje tikrai buvo gyvenama (Simniškytė 2013, 69 pav.). I P nuo piliakalnio kūrèsi Kupiškio miestelis (1 pav.), jo vardas sušmèžuoja 1480 m. kaip Krokuvos universiteto studento - Stanislavo Jonaičio iš Kupiškio (Stanislaus Hohannis de Cupyschky) - kilmès vieta. 1529 m. miestelis minimas kaip Lietuvos Didžiosios Kunigaikštystès valdovo Žygimanto Senojo valda (Baliulis 1997, p. 48). Manoma, jam vystytis padejo netoliese èjęs Vilniaus - Livonijos prekybos kelias bei i Š nuo piliakalnio, netoli Lėvens, prie Juodupès upelio buvęs Kupiškio dvaras, Pajuodupès vardu paminètas XVI amžiuje (Miškinis 2009 , p. 218). Nedidelis atstumas tarp piliakalnio, dvaro ir miesto leidžia manyti, kad tarp ju gyvavo chronologinis ar net funkcinis ryšys. 
Išvardyti požymiai skatina prielaidą: piliakalnio statusas vèlyvojoje priešistoreje buvo neeilinis ir jis atsirado ne dèl nuoseklios raidos, kai eilinè gyvenvietè palaipsniui išaugo į reikšmingą centrą, bet galbūt dèl socialinès organizacijos brandos ir sąmoningų elito potvarkių. Iškelta hipotezė, jog II tūkstantm. po Kr. pradžioje Kupiškio piliakalnis galèjęs būti savotiška pietinès Sèlos „sostine““ (Simniškytė 2005; 2013). Jame lokalizuojami XIII-XIV a. rašytiniuose šaltiniuose minimų istorinès Sèlos žemių - Medenès (Meddene) (Ciglis 2002, p. 18-19) ir Pelonès (Pelone) (Baranauskas 2015, p. 10) centrai. Buvus toki teritorinị ir politinị centrą teigia ir kiti autoriai (Žulkus, Jarockis 2013, p. 172, 55 pav., VIII žemèlapis).

\section{METODIKA}

I etapas. $2017 \mathrm{~m}$. atliktų geoarcheologinių ir geofizikinių piliakalnio žvalgymų tikslas buvo įvertinti archeologinio sluoksnio išlikimo laipsnị, jo storị ir paplitimą, išsiaiškinti perspektyvias kasinèjimų vietas, surinkti grunto mèginius geocheminiams tyrimams. Žvalgyta keliais būdais. Pirmiausia piliakalnio aikštelè ir iš dalies jo pašlaitè tirta geologiniu rankiniu kalamuoju gruntotraukiu. Eilemis skersai ir išilgai buvo padaryta 150 zondų su $5 \mathrm{~m}$ tarpu tarp jų ir keliolikos metrų tarpu tarp zondų eilių, esant poreikiui zondus išdèstant rečiau ar tankiau. Dèl kieto grunto ir vietomis nemažo gylio buvo zonduojama dviejų tipų grąžtų kombinacija (4 pav.). Iš pradžių buvo ịkalamas kietam gruntui skirtas $1 \mathrm{~m}$ ilgio ir $18 \mathrm{~mm}$ skersmens zondas, vèliau toje pačioje vietoje - pailgintas sudètinis $25 \mathrm{~mm}$ skersmens zondas. Dèl grunto kietumo ir įrankio lankstumo gilesnių nei 2,2 m gylio zondų įkalti nepavyko, o dèl nevienodo prietaisų skersmens kiek nukentejo stratigrafijos fiksavimo tikslumas.

Taip pat buvo atlikti geofizikiniai tyrimai georadaru ir magnetometru. Magnetometriniai žvalgymai atlikti gradiometru Bartington Grad 601. Žvalgyta padarius $0,5 \mathrm{~m}$ atstumą tarp jutiklių ir $0,25 \mathrm{~m}$ atstumą tarp signalų kiekviename profilyje. Žvalgyti
3940 m² $^{2}$ aikštelëje. Georadaru žvalgyta 2D metodu skersiniais ir išilginiais profiliais kas $10 \mathrm{~m}$ skenuojant visą piliakalnio aikštelę ir keletą profilių padarant jo šlaituose bei papèdèje. Naudotas georadaras Zond-12e (Radar Systems, Inc.) su $300 \mathrm{MHz}$ dažnio antena. Iš viso buvo padaryta 16 profilių, kurių bendras ilgis - 1093 m (Simniškytè, Vengalis 2018).

Iš gręžinių bei skirtingų jų gylių, taip pat vèlesnių perkasos tyrimų metu rinkti grunto mėginiai (apie 400 vnt.) laboratoriniams geocheminiams tyrimams. Išmatuotas visų jų magnetinis imlumas (MS) bei dalies mėginių organinès medžiagos (OM) ir fosforo $(P)$ kiekis. 5-50 g grunto pavyzdžių masès MS buvo matuojamas prietaisu Multifunction Capabridge meter MFK1-B (976 Hz dažniu, lauko intensyvumas - $200 \mathrm{~A} / \mathrm{m})$. OM kiekis nustatytas kaitinant $\left(5 \mathrm{~g}\right.$ bandinius $-105^{\circ} \mathrm{C} / 12$ val ir $550{ }^{\circ} \mathrm{C} / 4$ val ir apskaičiavus svorio nuostolius tarp šių intervalų). $P$ kiekis nustatytas ICP-OES sijotus $(<2 \mathrm{~mm})$ bandinius (0,5 g) ekstrahuojant $1 \mathrm{M} \mathrm{HCl} / 24 \mathrm{val}(50 \mathrm{ml})$.

II etapas. $2018 \mathrm{~m}$. archeologinių tyrimų tikslas buvo patikslinti piliakalnio chronologiją, apgyvenimo etapus, surinkti duomenis apie ùkí, mitybą, gyvenseną. Ištirta $20 \mathrm{~m}^{2}$ dydžio perkasa, gruntas tikrintas metalo detektoriumi, sijotas sietais su $5 \mathrm{~mm}$ dydžio akutemis. Atlikti paleobotaniniai, paleozoologiniai bei antrakologiniai medžiagos tyrimai. 12 méginių datuoti AMS ${ }^{14} \mathrm{C}$ metodu, straipsnyje kalibruotos radiokarboninès datos pateikiamos

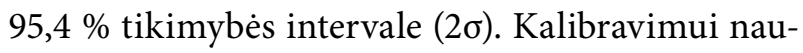
dota OxCal 4.4.2 programa (Bronk Ramsey 2009) ir IntCal 20 kalibravimo kreivè (Reimer et al. 2020). Tyrimai atlikti Vilniaus universiteto (VU), Gamtos tyrimų centro (GTC) bei Fizinių ir technologijos mokslo centrų (FTMC) laboratorijose.

\section{REZULTATAI}

Zondavimas. Zondavimas leido ịvertinti kultūrinio sluoksnio storị ir paplitimą dar prieš pradedant kasinèti, mat kerne užsilaikęs dirvožemis padeda 


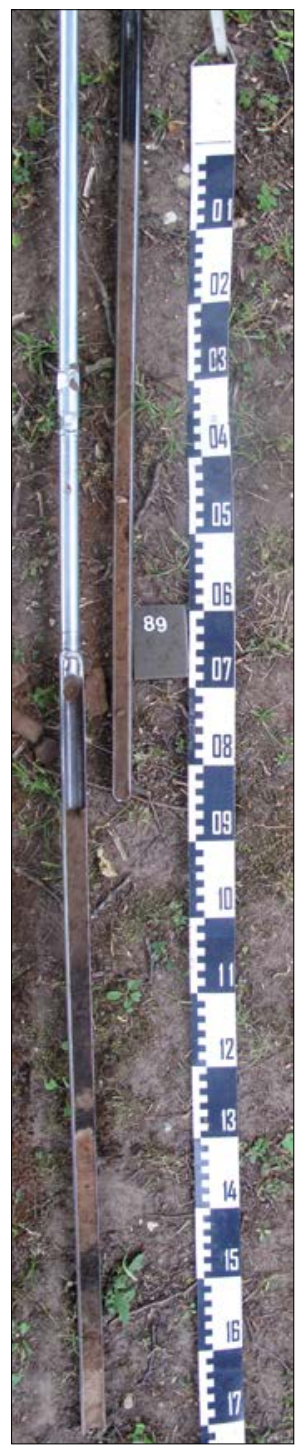

4 pav. Dviem gruntotraukiais ištrauktas grunto kernas. A. Simniškytès nuotr.

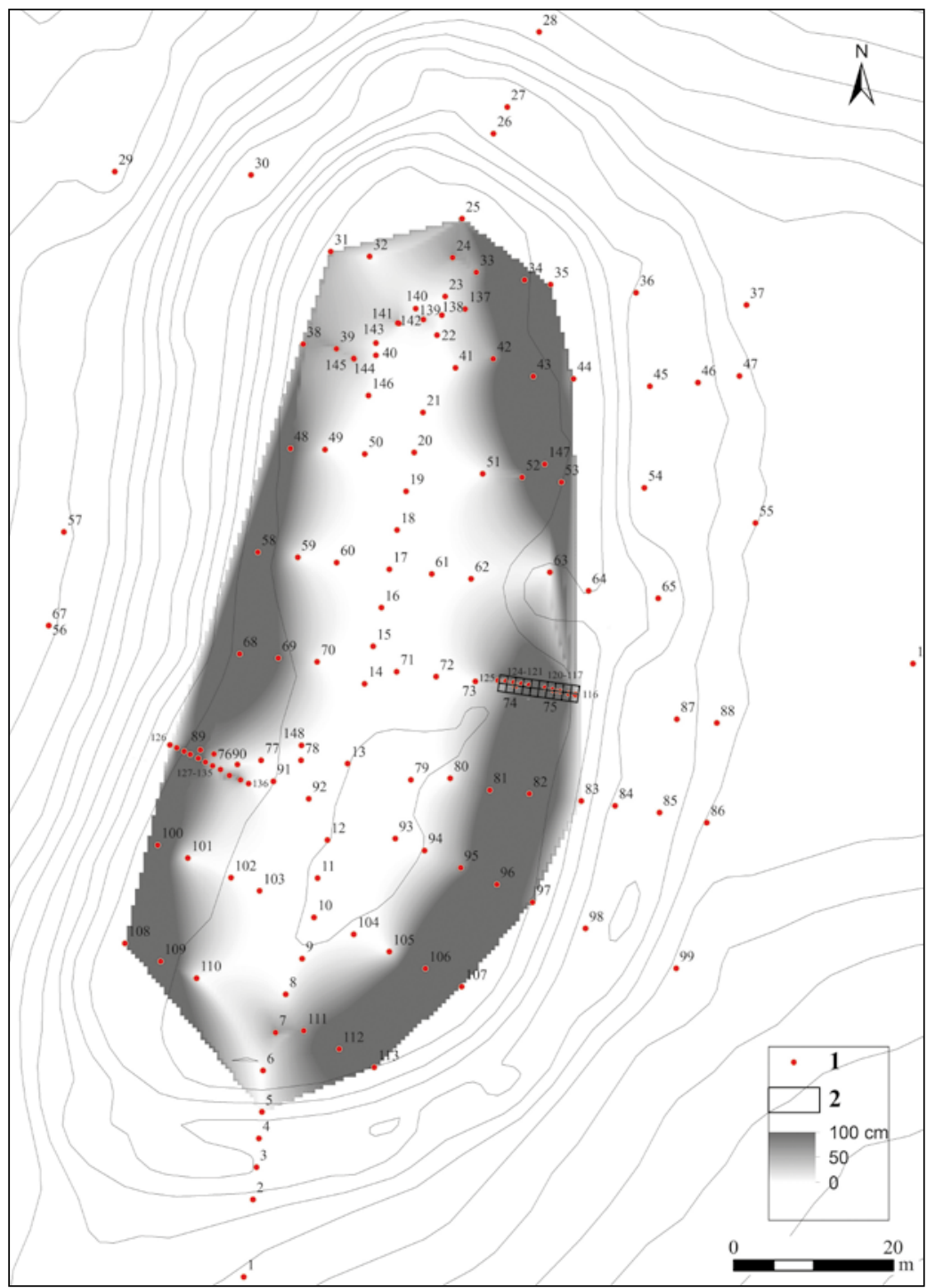

5 pav. Gręžiniai (1), perkasos vieta (2) ir kultūrinio sluoksnio storis ir paplitimas Kupiškio (Aukštupènų) piliakalnio aikštelèje pagal gręžinių duomenis. A. Simniškytès brëž. gana tiksliai fiksuoti zonduojamos vietos stratigrafiją (4 pav.). Centrinejje piliakalnio aikštelès dalyje kultūrinio sluoksnio nenustatyta (5 pav.), čia kieti vietomis karbonatiniai, vietomis išdūlèję geologiniai sluoksniai pasiekti iki 0,5-1 m gylyje, virš jų viršutinis dirvožemio sluoksnis buvo perklostytas. Antropogeninès kilmès sedimentai telkèsi aikštelès pakraščiuose, kur po iki $60 \mathrm{~cm}$ storio pilku viršutiniu dirvožemio sluoksniu pasiektą nevienalytị kultūrinị sluoksnị sudarè juosvi, pilki horizontai su rausvo, gelsvo ar balkšvo priemolio ar priesmèlio intarpais, su degèsiais arba be jų. Nejudinti natūralūs sluoksniai pasiekti, o kartais ir nepasiekti 1,5-2 m gylyje. Kas $5 \mathrm{~m}$ išdėstytuose zonduose aiškių antropogeninès kilmès pėdsakų aptikta ne tankiau kaip 2-3 gretimuose gręžiniuose, taigi, kultūrinis sluoksnis išlikęs maždaug iki $10 \mathrm{~m}$ atstumu nuo aikštelès krašto. Kelios atkarpos užfiksuotos išsamiau, kas 1 metras. Storiausias 1,5-2 m storio kultūrinis sluoksnis buvo maždaug už $6 \mathrm{~m}$ nuo aikštelès pakraščio, link centro 


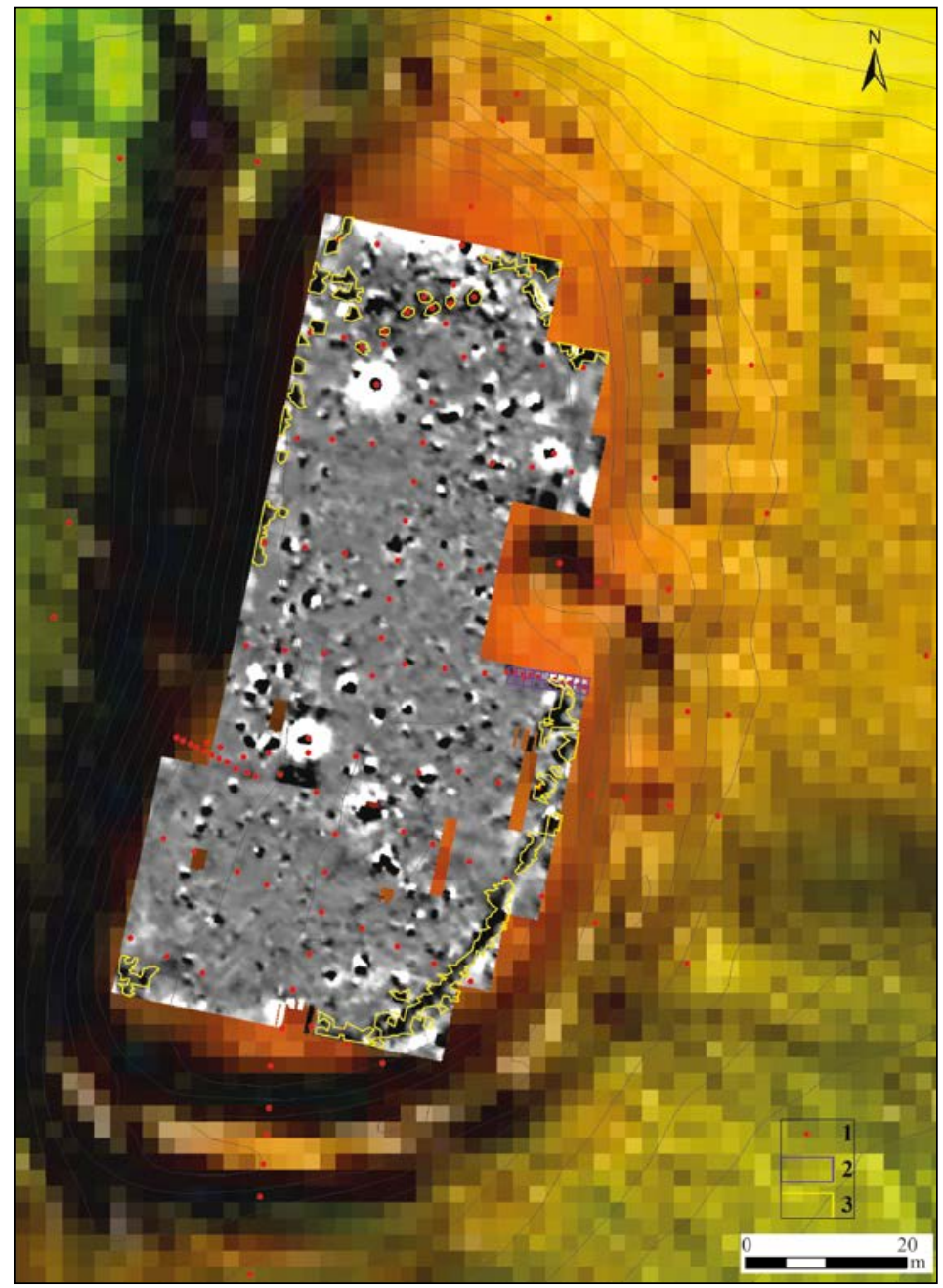

6 pav. Geofizikinių tyrimų magnetograma pagal R. Vengalio (2017) pateiktus duomenis. 1 - gręžinių vietos; 2 - perkasos vieta; 3 - potencialios archeologinès anomalijos. A. Simniškytès brèž.

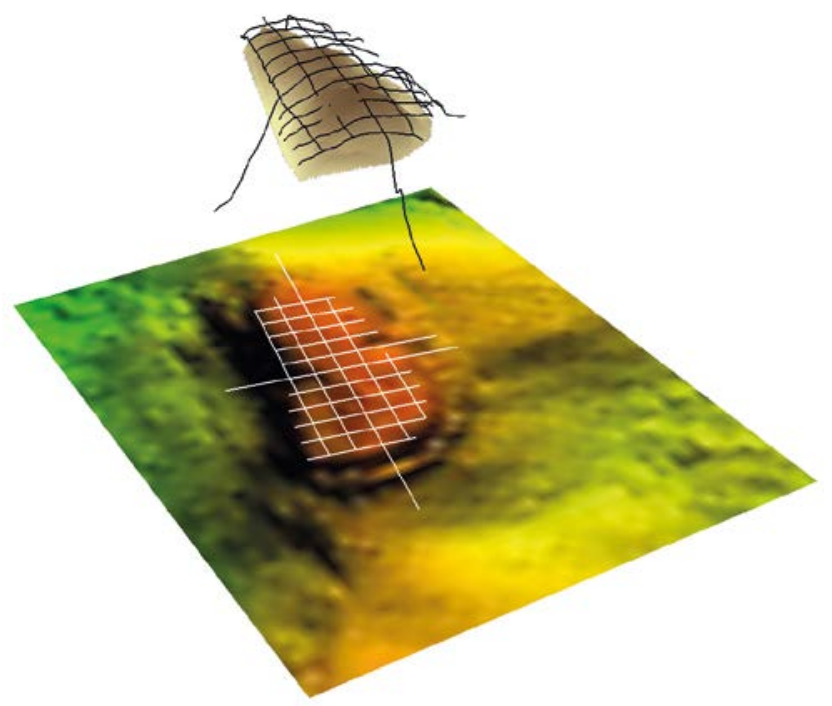

jis plonejjo, o maždaug ties 12-13-u metru nuo kalvos pakraščio jo nebeliko.

Geofizikiniai žvalgymai. Zondavimo duomenis savaip patvirtino geofizikiniai žvalgymai. Gradiometru galima lokalizuoti struktūras ịžemyje (duobes, griovius), degusius akmenis, jų sankaupas, taip pat geležies dirbinius. Didžiausias šio metodo trūkumas - jis parodo viską, kas gali sukelti didesnes magnetines anomalijas, taigi ir šiuolaikines šiukšles, vinukus, kamštelius ir pan. Ivairaus ryškumo magnetinių anomalijų buvo gausu visoje aikštelèje, tačiau didžioji jų dalis šiuolaikinès geležinès šiukšlès. Pašalinus numanomus magnetinius triukšmus, didžioji potencialiai archeologinių anomalijų dalis išsidèsčiusi aikštelès pakraščiuose (6 pav.). Vienur jos sudarè ištisinę liniją, vidutiniškai 1,5-2 m pločio, kitur išsiskirstè $\mathfrak{i}$ atskiras anomalijas. Šis objektas gali žymèti sudegusių konstrukcijų (ittvirtinimų) vietas. Kadangi anomalijų vietos, apie jas dar nežinant, jau prieš tai buvo zonduotos gruntotraukiu, papildomai patikrintos tik išryškejjusių septynių anomalijų vietos šiaurinèje aikštelès dalyje. Keturiose jų sekliai, maždaug $20-45 \mathrm{~cm}$ gylyje, aptiktas degèsingas 10-15 cm sluoksnelis, penktos vietoje $20 \mathrm{~cm}$ gylyje susidurta su neprakalamu akmenų sluoksniu, dar dviejose - natūralūs sluoksniai. Natūralių sedimentų nustatyta ir keliose anomalijose su neigiamu fonu, kurių kilmè paprastai būna stambus geležinis objektas (Simniškytè, Vengalis 2018).

7 pav. Georadaro profilių vietos (apačioje) ir dabartinio žemès paviršiaus (juodos linijos) bei paleoreljefo santykis (rusva spalva) (viršuje) pagal R. Vengalio (2017) pateiktus duomenis. A. Simniškytès brëž. 

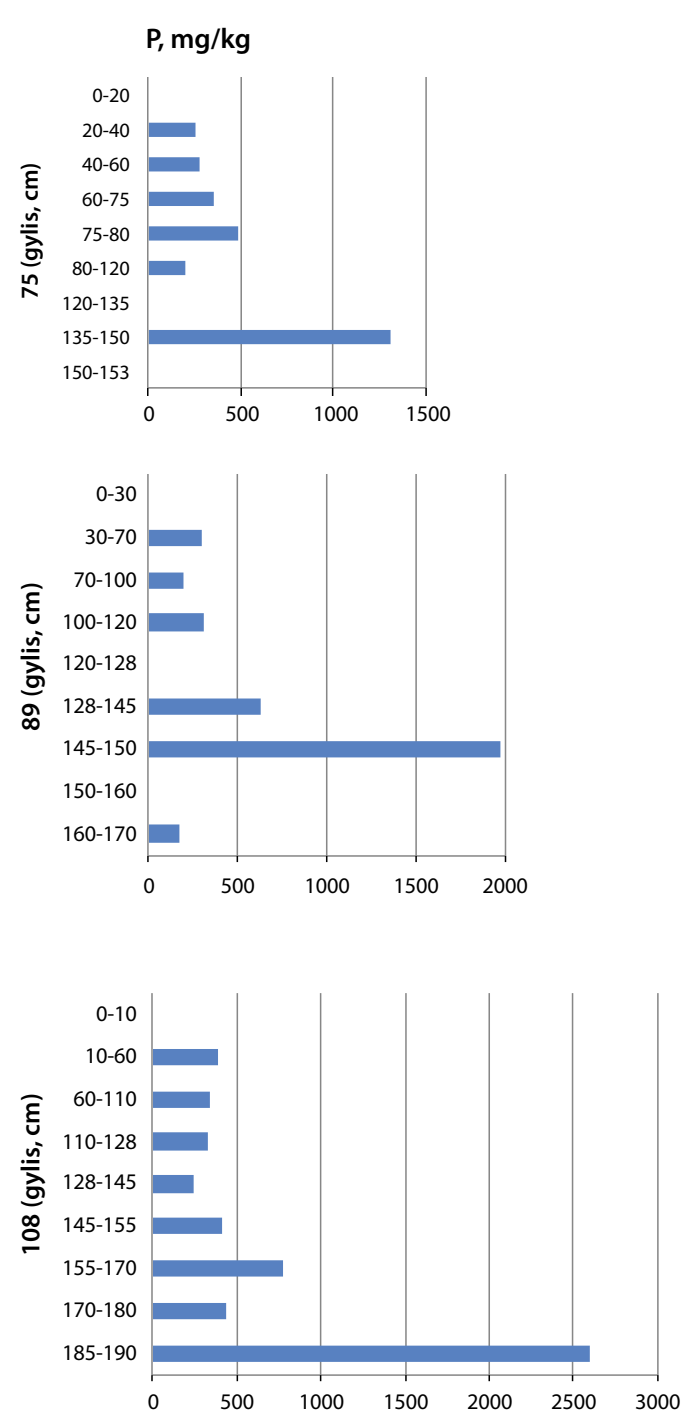

$\mathrm{OM}, \%$

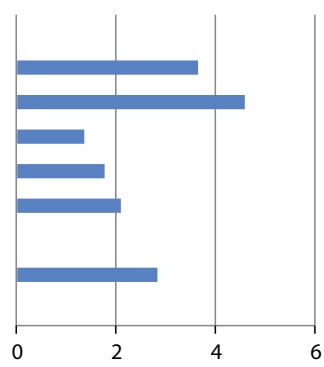

$M S, 10^{-9} \mathrm{~m}^{3} \mathrm{~kg}^{-1}$
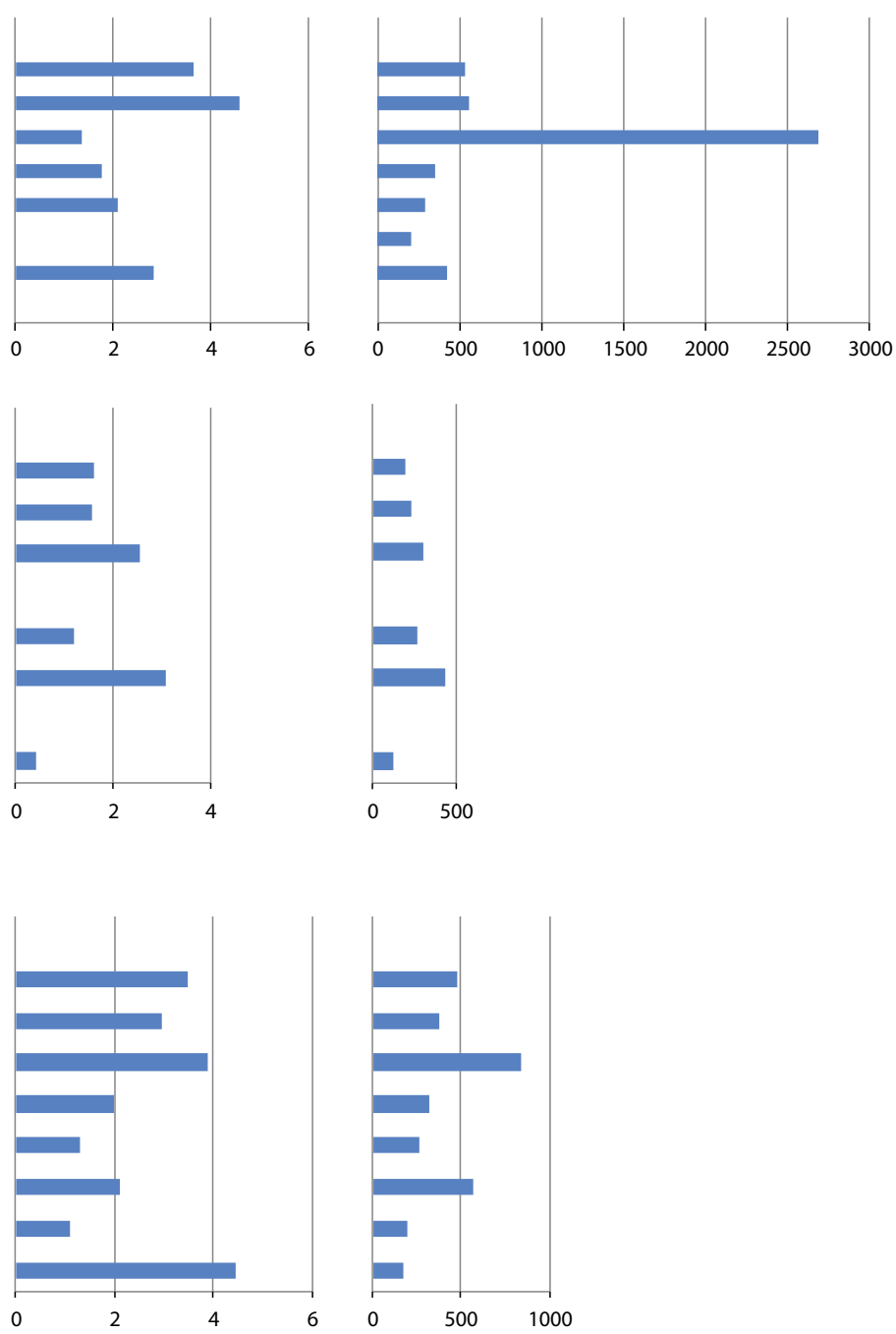

8 pav. Vertikalus grunto savybių (MS, P, OM) matavimo reikšmių kitimas 75, 89 ir 108 gręžiniuose. Parenge A. Simniškytė.

Atlikti žvalgymai georadaru suteikè kitokio pobūdžio informaciją. Jie parodè tiriamos vietos stratigrafiją pagal skirtingos sudèties sluoksnių konfigūraciją. Nustatyta nevienalytė kalvos sandara - jos pagrindą sudaro smulkus gruntas (smulkus smèlis, priemolis, molis), o viršutinè dalis kur kas stambesnès frakcijos. Kaip svarbiausią rezultatą galima ịvardyti atkurtą pirminị reljefą, buvusị šioje vietoje iki irengiant piliakalnị (7 pav.). Nustatyta, kad piliakalnis buvo įrengtas kalvoje su gana smailia viršūne, jos R šlaitas kiek nuolaidesnis, o V - status. Kalva tęsèsi Š-P kryptimi ir buvo ị P nuo piliakalnio esančios pakilumos tęsinys. Irrenginejjant ir pertvarkant piliakalnị, kalvos pakraščiuose buvo supilti grunto sluoksniai: paviršius paaukštintas ir padaryta plokščia aikštelè stačiais šlaitais (Simniškytė, Vengalis 2018).

Laboratoriniai tyrimai. MS yra grunto savybè, rodanti magnetinių geležies mineralų (magnetito ar maghemito) buvimą dirvožemyje. Paprastai viršutinio jo sluoksnio MS didesnis nei j̧žemio. Aukšta temperatūra, degimas yra viena iš priežasčių, dèl kurių MS didejja. Vykstant degimui, nedaug i̇magnetinti geležies oksidai molio ir dumblo dalelèse 


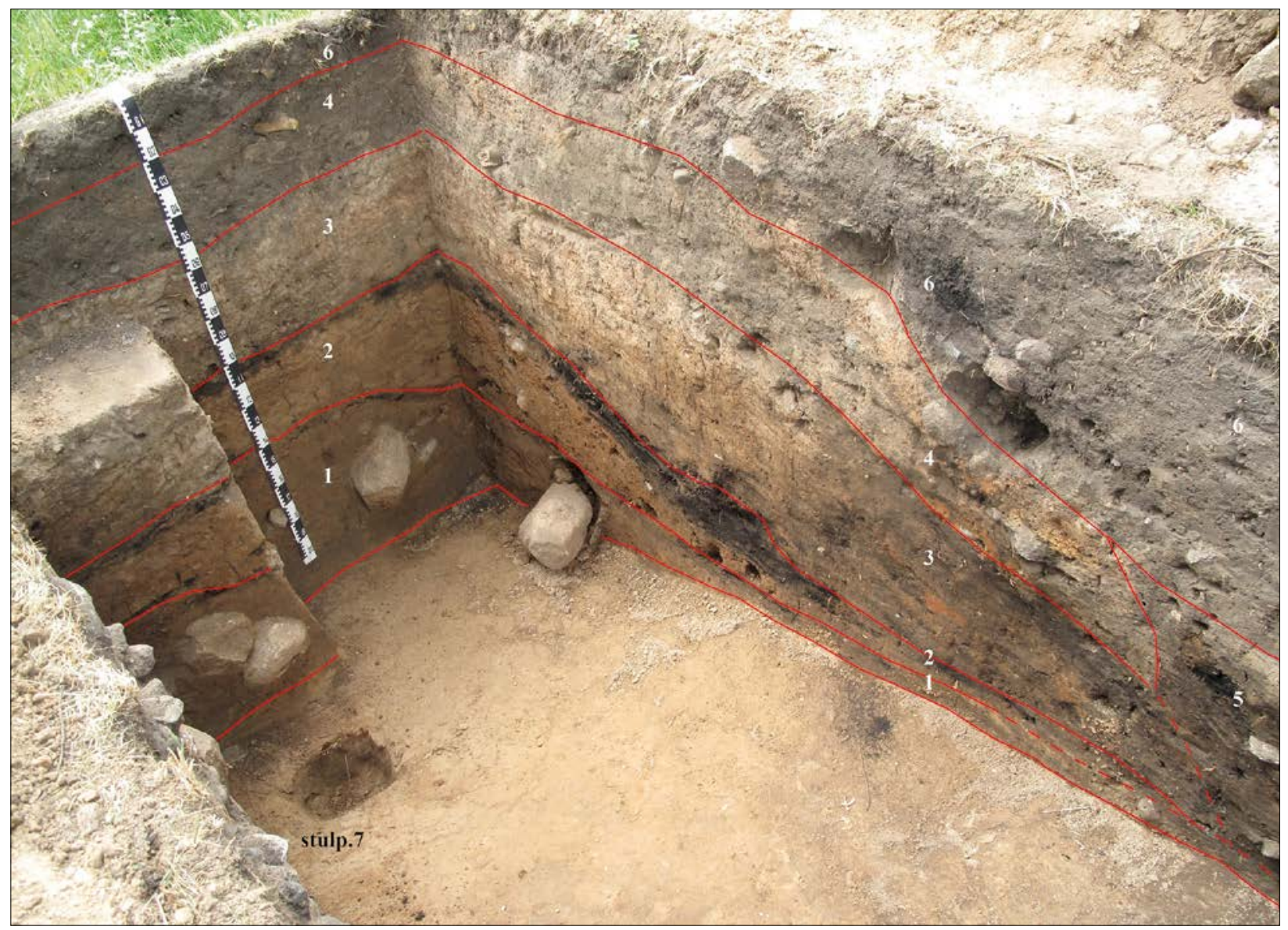

9 pav. Perkasos R ir P sienelès pylimo vietoje (baltais skaitmenimis sužymėti tekste minimi 1-6-as kontekstai). A. Simniškytės nuotr.

virsta labai i̇magnetintais, todèl MS šuoliai gali padèti aptikti gaisrų, židinių, krosnių, geležies gavybos ar apdirbimo vietas, taip pat karščio paveiktų sudilusių dirbinių dalelių buvimą (Clark 1990; Dearing 1994).

Iš 400 bandinių reikšmingai padidèjęs imlumas (> 2 SD) nustatytas vos $4 \%$, t. y. 15 bandinių iš 13 gręžinių. Visi didesnio imlumo mėginiai paimti aikštelès pakraščiuose, aikštelès viduryje sedimentai magnetiškai buvo „ramūs“. MS vertikalaus kitimo tendencijų ir ryšio su konkrečiais horizontais nenustatyta.

$P$ ir OM kiekis rodo kiek kitaip gruntą keičiančios žmogaus veiklos poveikį. Šių savybių pasiskirstymas gali parodyti zonas ar horizontus, susijusius su buitine veikla, ypač buitinių atliekų zonomis, taip pat gyvulių laikymo vietomis, kur kaupiasi mėšlas (Aston et al. 1998; Holliday, Gartner 2007; Wilson et al. 2008; Salisbury 2016). P ir OM tyrimais buvo siekta ìvertinti šių savybių vertikalaus kitimo tendencijas. Iš viso buvo paimta 60 bandinių iš nevienodo gylio. 4-iuose gręžiniuose aikštelès V ir R pakraštyje (nr. 53, $75,89,108$ ) bei perkasoje nustatytas reikšmingas $P$ kiekio padidejjimas antropogeninių sedimentų apačioje (8 pav.). Didesni OM kiekiai rodo, kad $P$ yra in situ ir organinès kilmès, o ne išsiplovimo procesų ar mineralų (pvz., apatito) dūlejjimo rezultatas.

Archeologiniai kasinèjimai. Pagal gruntotraukio kernus ir geofizikinius žvalgymus vieta tirti pasirinkta aikštelès $\mathrm{R}$ pakraštyje. Paaiškejo, kad čia buvo maždaug $2 \mathrm{~m}$ aukščio pylimas, kurio viršus perkasos R dalyje pasiektas jau 15-20 cm gylyje (9, 

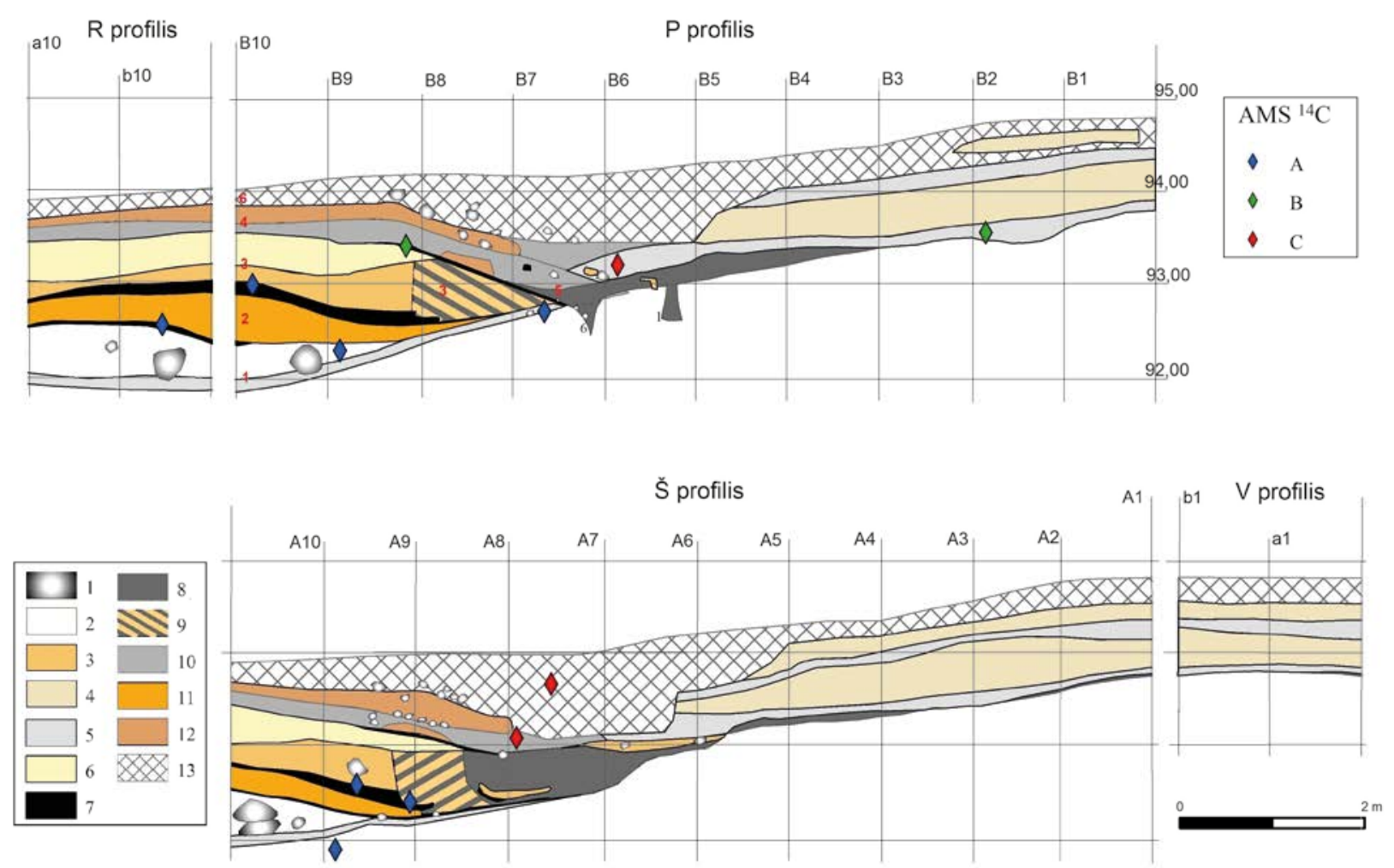

10 pav. Perkasos sienelių pjūviai ir AMS ${ }^{14} \mathrm{C}$ datų išsidèstymas. A - mėginiai, datuoti VIII-V a. pr. Kr.; B - mėginiai, datuoti VVI a. po Kr.; C - mėginiai, datuoti VIII-X a. po Kr. Sutartiniai ženklai: 1 - akmenys; 2 - pilkšvai gelsvas smèlis; 3 - priesmèlis; 4 - aleuritingas kietas gruntas; 5 - ankstesni paviršiai; 6 - išdūlèjęs aleuritingas gruntas; 7 - degèsių sluoksnis; 8 - juosvas smèlis; 9 - pilkšvas priesmèlis; 10 - pilkas smèlis; 11 - priemolis; 12 - priemolis su akmenimis; 13 - viršutinis dirvožemio sluoksnis. Raudonais skaitmenimis sužymèti tekste minimi 1-6-as kontekstai. A. Simniškytės brěž.

10 pav.). Pylimas išlikęs ne visas, jo rytinis (išorinis) šlaitas, greičiausiai, buvo nukastas vèliau formuojant griovị, dabar juosiantị aikštelę. Išlikusi pylimo dalis - maždaug 3-4 m pločio, 1,8-2 m aukščio. Po juo $2 \mathrm{~m}$ gylyje - pirminis paviršius, nuo kalvos pakraščio kilęs aikštelès centro link - kartojo kalvos paleoreljefą. Pirminio paviršiaus lygmenyje buvo susiklostęs 5-20 cm storio pilkšvas kultūrinis sluoksnis; jame aptikta negausių archeologinių radinių. Po juo - smulkaus moreninio priesmèlio izžemis, pylimo vietoje slūgsantis maždaug 205-210 cm gylyje.

Pirminio paviršiaus lygmuo sąlygiškai pavadintas 1-u kontekstu, jam priskirtos 36 smulkios keramikos šukès, daugiausia - brūkšniuotu paviršiumi (1 lentelè). Beveik visos šukès rastos perkasos $V$ dalyje po $1 \mathrm{~m}$ storio perklostytais sedimentais. Neteigtina, kad šis kontekstas yra iš būtent ir tik ankstyviausio kalvos etapo. Viena lipdytinio indo į vidų lenktu pakraštèliu dalis, puošta geometriniu ornamentu, datuojama antra I tūkstantm. po Kr. puse, galbūt trečiu I tūkstantm. ketvirčiu (19: 7 pav.). Perkasos V dalyje ižzemyje (125$140 \mathrm{~cm}$ gylyje) išryškèjo $115 \times 95 \mathrm{~cm}$ dydžio ir vos $5 \mathrm{~cm}$ gylio dèmè be radinių (objektas 1) (11, 12 pav.). Angliukas iš šio objekto AMS ${ }^{14} \mathrm{C}$ datuotas V a. - VI a. po Kr. viduriu (FTMC-35-11: 1599 \pm 40 BP) (2 lentelè, 13 pav.). Centrinèje perkasos dalyje kultūrinio sluoksnio apačioje 130-140 cm gylyje aptiktos kelios šukelès brūkšniuotu ir lygiu paviršiumi, čia pat rasta ir XX a. geležinè vinis. Tai rodo, kad pirminiame paviršiuje esama įvairių laikotarpių veiklos pėdsakų dèl greičiausiai vèlesnių piliakalnio pertvarkymo darbų. Vèlesnès veiklos priemaišų nerasta tik perkasos $\mathrm{R}$ dalyje buvusiame pirminiame paviršiuje po pylimu, tačiau čia jokių datuojančių radinių neaptikta, todèl 


\begin{tabular}{|l|c|c|c|c|c|c|c|c|c|c|c|c|}
\hline \multicolumn{1}{|c|}{ Kontekstai } & BR & L & KR & GL & GR & GN & $\check{\mathbf{Z}}$ & $\mathbf{?}$ & Viso, vnt. & Viso (g) & $\overline{\mathbf{x}}(\mathbf{g})$ & $\tilde{\mathbf{x}}(\mathbf{g})$ \\
\hline K.1 & 23 & 7 & & 2 & & & & 4 & $\mathbf{3 6}$ & $\mathbf{2 0 8}$ & 5,8 & 3,4 \\
\hline K.2 & & & & & & & & & & & & \\
\hline K.3 & 36 & 3 & & & & & & 2 & $\mathbf{4 1}$ & $\mathbf{2 9 2}$ & 7,1 & 4,4 \\
\hline K.4 & 6 & 2 & & 1 & & & & & $\mathbf{9}$ & $\mathbf{2 9}$ & 3,3 & 2,9 \\
\hline K.5 & 23 & 22 & 35 & 24 & 3 & & 3 & 5 & $\mathbf{1 1 5}$ & $\mathbf{7 0 3}$ & 6,1 & 4,8 \\
\hline K.6 & & 9 & 2 & 3 & 2 & 1 & & 1 & $\mathbf{1 8}$ & $\mathbf{1 2 2}$ & 6,8 & 4,1 \\
\hline Viso, vnt. & $\mathbf{8 8}$ & $\mathbf{4 3}$ & $\mathbf{3 7}$ & $\mathbf{3 0}$ & $\mathbf{5}$ & $\mathbf{1}$ & $\mathbf{3}$ & $\mathbf{1 2}$ & $\mathbf{2 1 9}$ & $\mathbf{1 3 5 4}$ & & \\
\hline Viso $(\mathbf{g})$ & $\mathbf{5 0 1}$ & $\mathbf{2 5 2}$ & $\mathbf{2 9 8}$ & $\mathbf{1 8 5}$ & $\mathbf{5 3}$ & $\mathbf{2 , 3}$ & $\mathbf{1 0 , 5}$ & $\mathbf{5 2}$ & & & & \\
\hline$\overline{\mathrm{x}}(\mathrm{g})$ & 5,8 & 5,7 & 8,1 & 6,2 & 10,6 & & 3,5 & 4,3 & & & & \\
\hline$\tilde{\mathbf{x}}(\mathrm{g})$ & 3,8 & 3,2 & 5,4 & 4,7 & 6,2 & & 2,6 & 3,15 & & & & \\
\hline
\end{tabular}

1 lentelè. Keramikos rūšių (BR - lipdyta brūkšniuota, L - lygi, KR - kruopèta, GL - gludinta, GR - grublèta, GN - gnaibyta, $\check{Z}$ - žiesta, ? - nenustatyta) pasiskirstymas tekste minimuose kontekstuose (K) vienetais (vnt.) ir

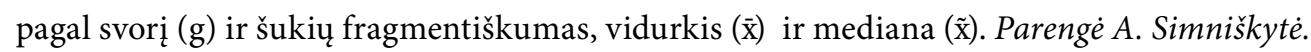

ankstyviausios antropogeninès veiklos kalvoje chronologija kol kas lieka nenustatyta.

Rytinis aikštelès pakraštys buvo sutvirtintas akmenų, grunto ir medžio konstrukcija. Jos pagrindą sudarè atskiri $30 \times 30,40 \times 40 \mathrm{~cm}$ ir pan. dydžio rieduliai, užpilti priesmèliu. Vidinis šio sampilo šlaitas vos 1,5 m atstumu nuo dabartinio išorinio šlaito, jo aukštis - 50-60 cm (10 pav.). Granuliometriškai horizonto savybės beveik nesiskyrè nuo paleopaviršiui būdingų savybių (aleuritingas priesmèlis), ant akmenų greičiausiai buvo užpiltas čia pat iškastas gruntas. Sampilo viršuje aptikta medinès konstrukcijos liekanų - sudegusių alksninių kuolų fragmentai Š-V kryptimi (11: A pav.). Vidiniame šlaite aptikta pasklidusių 15-20 cm akmenų, tarp jų - degusios ąžuolo medienos bei kelios gyvulių kaulų skeveldros (47 g); po akmenų sluoksniu - stulpaviete 7 pavadinta $25 \times$ $28 \mathrm{~cm}$ dydžio ir $25 \mathrm{~cm}$ gylio igilinta struktūra su $10 \times$ $15 \mathrm{~cm}$ dydžio akmeniu jos šone ( 9 pav.). Kiek atokiau ižzemyje išryškèjo dar septynių panašių formų, gal ir paskirties, igilintos struktūros, šešios (Nr. 1-6) - apskritos ar ovalios formos $16 \times 16-40 \times 40 \mathrm{~cm}$ skersmens ir 5-40 cm gylio, viena (Nr. 8) - keturkampio formos (11 A pav., 14 pav.). Paleobotaniškai išanalizavus 4-ių stulpaviečių $(2,3,4,7)$ mėginius 3-se aptikta augalų vaisių ir sèklų.
Stratigrafiškai ankstyviausia galètų būti po akmenų ir grunto sampilu aptikta stulpavietė 7. Jos ryšys su atokiau buvusiomis stulpavietemis lieka neaiškus, pastarosios gali būti kiek vèlesnių etapų segmentai. AMS ${ }^{14} \mathrm{C}$ datuoti stulpavietèje 7 rastas miežio grūdas (FTMC-PC42-2: 2453 $\pm 30 \mathrm{BP}$ ) ir trys anglies mèginiai: keturkampès stulpavietès 8 (FTMC-35-7: 2477 \pm 41 BP), kuolų konstrukcijos (FTMC-35-8: 2376 \pm 41 BP) bei angliuko, įsiterpusio tarp akmenų pylimo vidinèje puseje (FTMC-35-9: 2486 $\pm 41 \mathrm{BP}$ ). Visos radiokarboninès datos patenka ị kalibravimo kreivès Halštato suplokštèjimą ir apima vidutiniškai 350 metų laikotarpi - VIII-V a. pr. Kr. (2 lentele, 13 pav.).

Sudegus pirmiesiems įtvirtinimams pylimas buvo paaukštintas ir nuo pirminio kalvos paviršiaus siekè 1-1,1 m (2-as kontekstas) (9, 10 pav.). Šiame horizonte nustatyta daugiau smulkių grunto frakcijų, tad galima teigti, kad jis buvo kibesnis ir atsparesnis erozijai. Aukštinant pylimą šalia galejo formuotis griovys, galbūt - dabartinio griovio vietoje, o gruntą kasė iš giliau, pasiekdami moreninị priemolį. Priemolio pylimą tvirtino medinių rąstų konstrukcija, kuriai sudegus susidarè iki 10-12 cm storio degèsių sluoksnis. Apanglejjusios trijų rąstų (dviejų - ažuolo, vieno - beržo) dalys gulejo išilgai ir skersai pylimo (11: B pav., 15 pav.). Kitų radinių nerasta. 


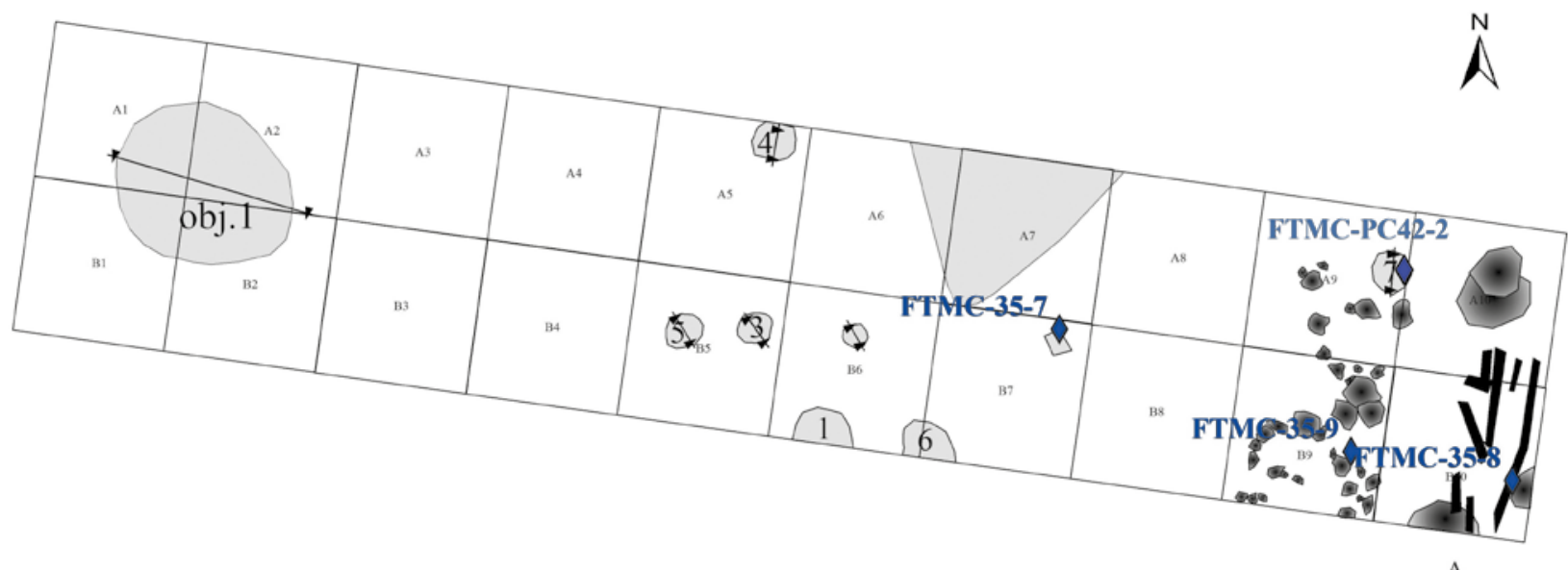

A

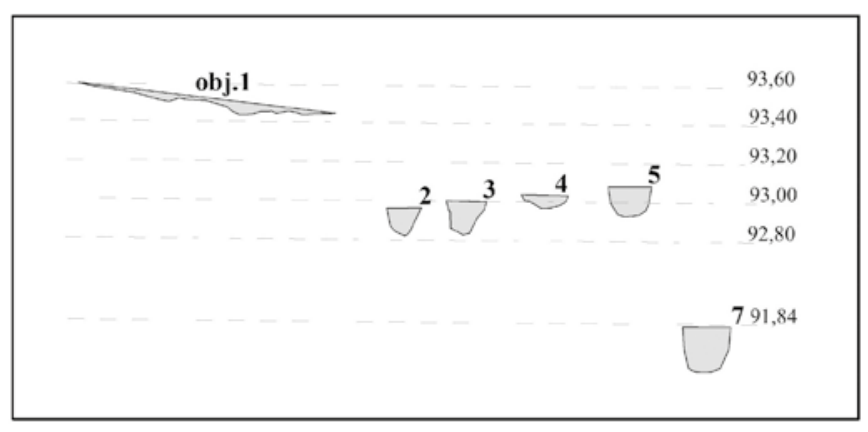

$\mathrm{D}$

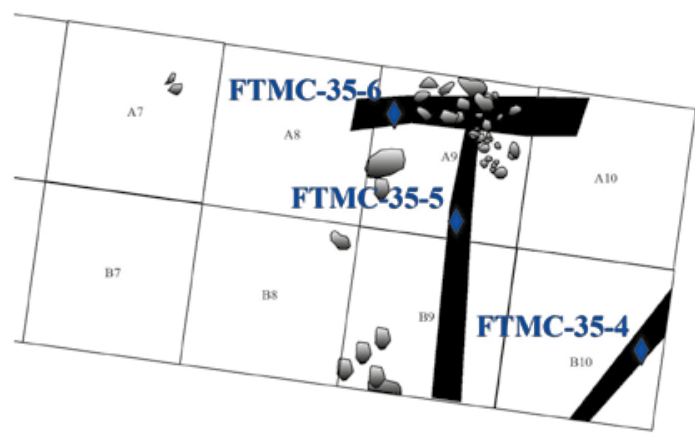

B

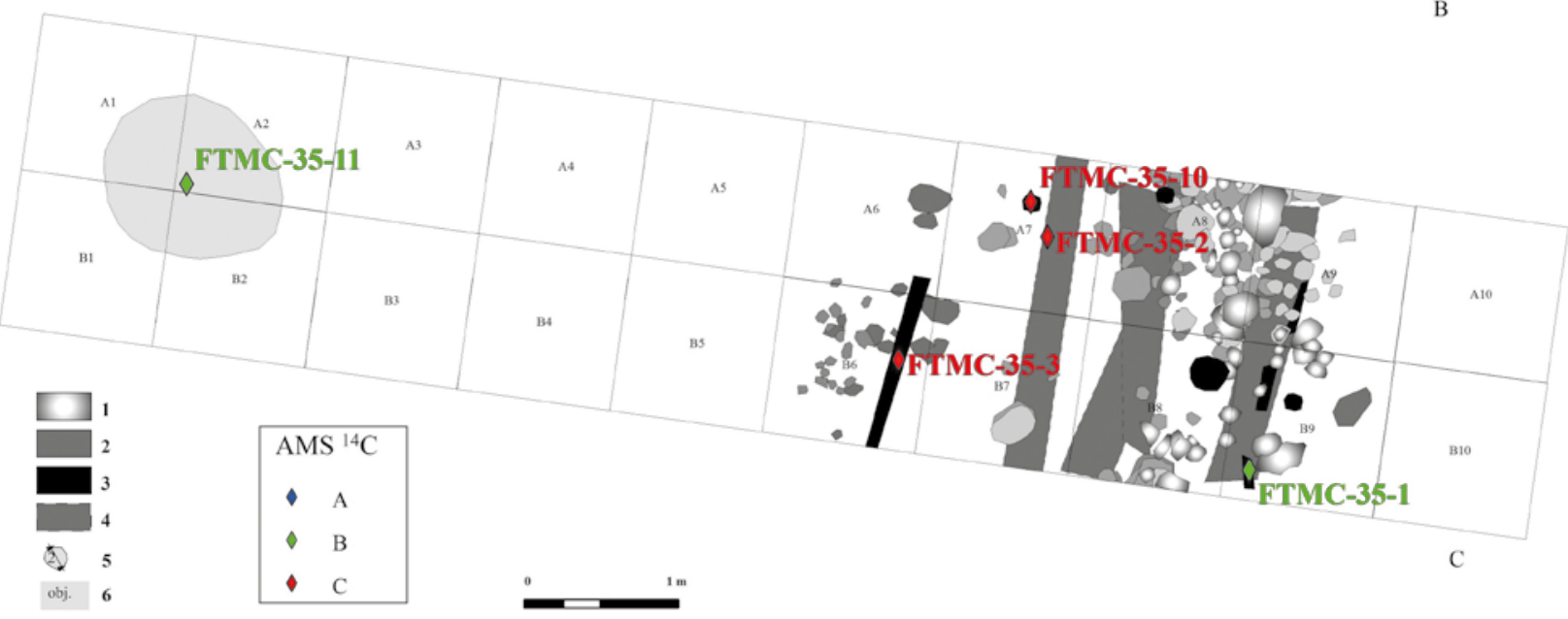

11 pav. Perkasos planas ir AMS ${ }^{14} \mathrm{C}$ datų išsidèstymas: A - 1-as kontekstas, ịtvirtinimai pylimo vietoje - 140-170 cm gylyje; B - 2-as kontekstas, ịtvirtinimai pylimo vietoje - 110-140 cm gylyje; C - 3-ias ir 4-as kontekstai, ịtvirtinimai pylimo vietoje - 30-110 cm gylyje; D - igilintų struktūrų pjūviai. Sutartiniai ženklai: 1, 2 - akmenys (30-170 cm, nuo šviesesnio prie tamsesnio), 3 - apanglèjusi mediena; 4 - rąstų (?) kontūrai; 5 - spejjamos stulpavietès ir jų pjūvių vietos; 6 - spejjami neaiškios paskirties objektai. AMS ${ }^{14} \mathrm{C}$ ženklų paaiškinimus žr. 10 pav. A. Simniškytès brèž. 


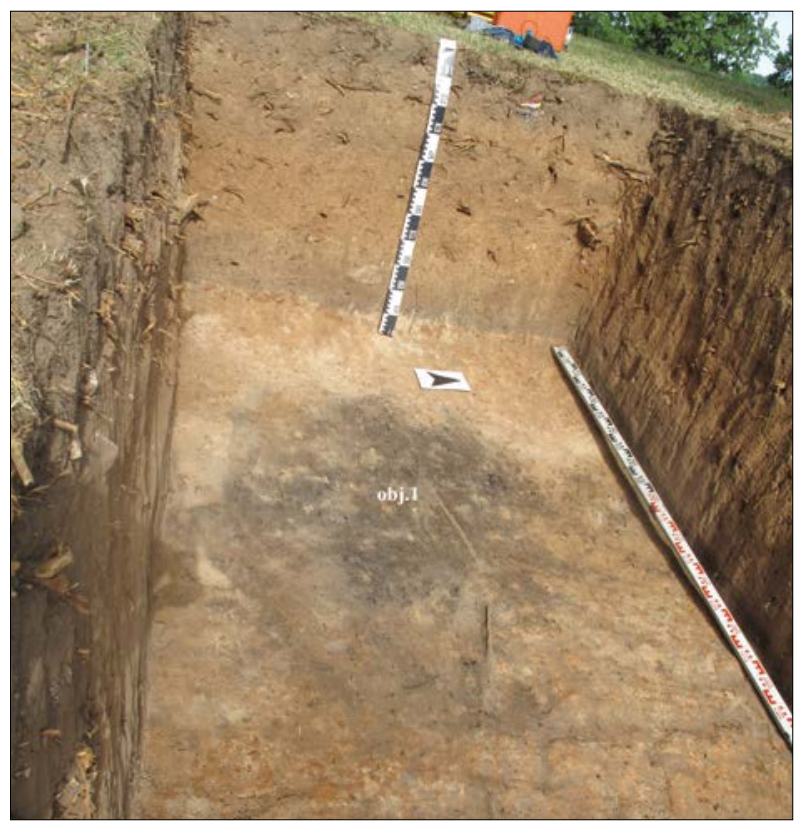

12 pav. Objektas 1. A. Simniškytès nuotr.

Datavus rąstų anglis, nustatytos tarpusavyje ir i jau minètas panašios nekalibruotos datos (FTMC35-4: 2423 \pm 43 BP; FTMC-35-5: 2469 \pm 43 BP; FTMC35-6: 2454 $\pm 41 \mathrm{BP})$, kurios irgi patenka ị kalibravimo kreivès Halštato suplokštejjimą ir apima VIII-V a. pr. Kr. (2 lentelè, 13 pav.). Darant prielaidą, kad 2-o konteksto mėginiai yra iš vieno radioaktyviosios anglies rezervuaro, t. y. iš esmés priklauso tai pačiai konstrukcijai ir tam pačiam ịvykiui, buvo atliktas jų nekalibruotų datų kombinavimas naudojantis R_Combine funkcija (Bronk Ramsey 1998, p. 461474). Gauta statistiškai pagrịsta kombinuota ${ }^{14} \mathrm{C}$ data $-2449 \pm 25 \mathrm{BP}\left(\chi^{2}=0,6<6=\chi^{2} 0,05(2)\right.$. Ją perkalibravus, datavimo susiaurinti nepavyko, išskirtas labiausiai tikètinas datavimo intervalas: 752412 BC $(2 \sigma)$.

Trečią kartą pylimas paaukštintas iki 1,6-1,8 m (3-ias kontekstas), užpiltas priemolingas gruntas buvo smulkios, mikrosluoksnelinès struktūros. Apatineje šio sluoksnio dalyje molio ir aleurito dalelių daugiau nei viršutineje. Greičiausiai, moreninis priemolis viršutinëje dalyje išdūlëjo, ir smulkios mineralinès dalelès išsiplovè. Vidinę sampilo pašlaitę buvo nugulęs tamsokas sluoksnis lyg iš grunto, turinčio pakaitomis daugiau ir mažiau organikos (pvz., velènos). Jame rasta beveik $300 \mathrm{~g}$ keramikos (41 vnt.), šukès kiek stambesnès nei 1-ame kontekste $(\overline{\mathrm{x}}-7,1 \mathrm{~g}, \tilde{\mathrm{x}}-$ 4,4 g), beveik visos - brūkšniuotu paviršiumi (1 lentelè, 18 pav.). Surinkta per 120 g zooarcheologinès medžiagos (t. y. daugiau nei trečdalis rastosios): iš iki rūšies identifikuotų kaulų daugiau nei pusę sudarè kiaulès kaulai (22 pav.). Horizonto viršuje - degèsių sluoksnelis (16 pav.), jame planigrafiškai išryškejjo spejjamų rąstų kontūrai (11: C pav.). Vidinejje pylimo puseje aptiktos minètos stulpavietes primenančios struktūros. Pagal radinius ir keturkampès stul-

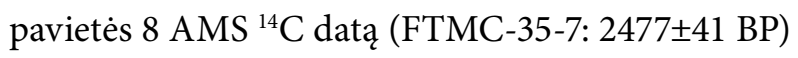
šis kontekstas taip pat priklausytų brūkšniuotosios keramikos kultūros laikotarpiui. Tačiau datavimas lieka neaiškus, mat vienas iš spejjamų rąstų datuotas IV a. po Kr. viduriu - VI a. po Kr. viduriu (FTMC35-1: 1597 \pm 44 BP).

Pylimą rekonstravus ketvirtą kartą, tyrimų vietoje jis buvo $2 \mathrm{~m}$ aukščio ir 3-4 m pločio (4-as kontekstas). Pilkas gruntas užplūktas gelsvai rusvu priemoliu, sutvirtintu akmenimis (9 pav.). Pylimo viršuje, t. y. vos 15-20 cm gylyje nuo žemės paviršiaus, buvo anglių sankaupų - sudegusių stulpų vietų (?), o vidinèje pylimo pašlaiteje rastos kelios sudegusių rąstų dalys. Iš viso šiam kontekstui priskirti trys konstrukciniai pušies ir vienas ąžuolo elementai. Datavus tris mėginius (FTMC-35-2: 1130 \pm 40 BP; FTMC-353: $1172 \pm 40$ BP; FTMC-35-10: 1077 \pm 40 BP), jie apima 137-214 metus - antrą VIII a. ketvirtị - pirmą XI a. ketvirtị (11: C pav.). Pritaikius nekalibruotų ${ }^{14} \mathrm{C}$ datų kombinavimo metodą gauta statistiškai pagrịsta kombinuota ${ }^{14} \mathrm{C}$ data: $1127 \pm 30 \mathrm{BP}\left(\chi^{2}=2,8<6=\right.$ $\chi^{2} 0,05(2)$. Ją perkalibravus, išskirtas labiausiai tikè-

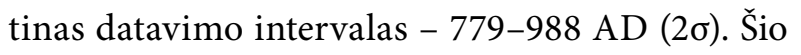
laikotarpio radinių neaptikta, visi 4-o horizonto radiniai buvo ankstesnių laikų šukès ir itin smulkios $(\bar{x}-3,3$ g, $\tilde{x}-2,9$ g) (1 lentelè). Galima teigti, kad pylimas buvo paaukštintas ankstesnių laikų kultūriniu piliakalnio sluoksniu. 


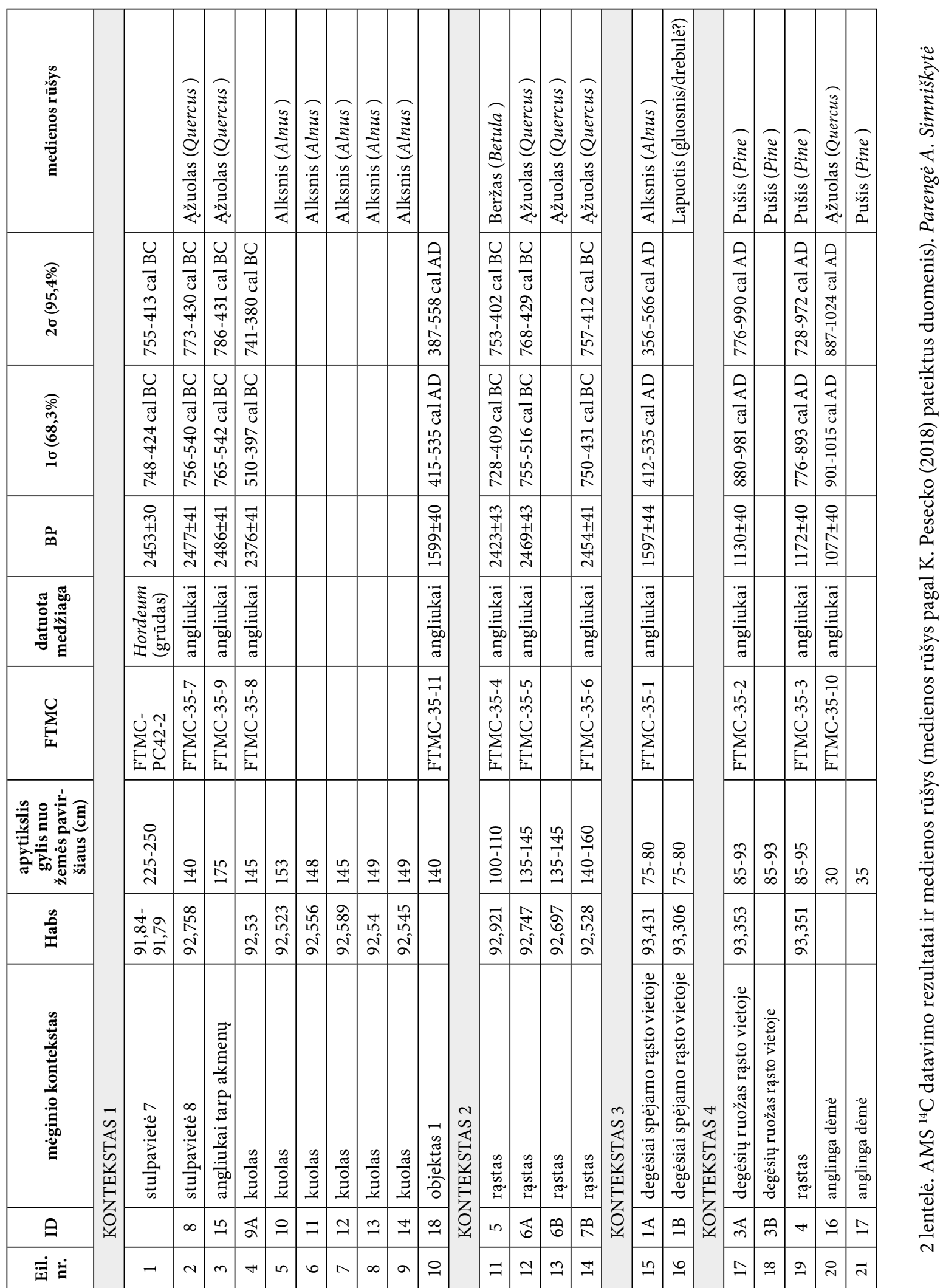




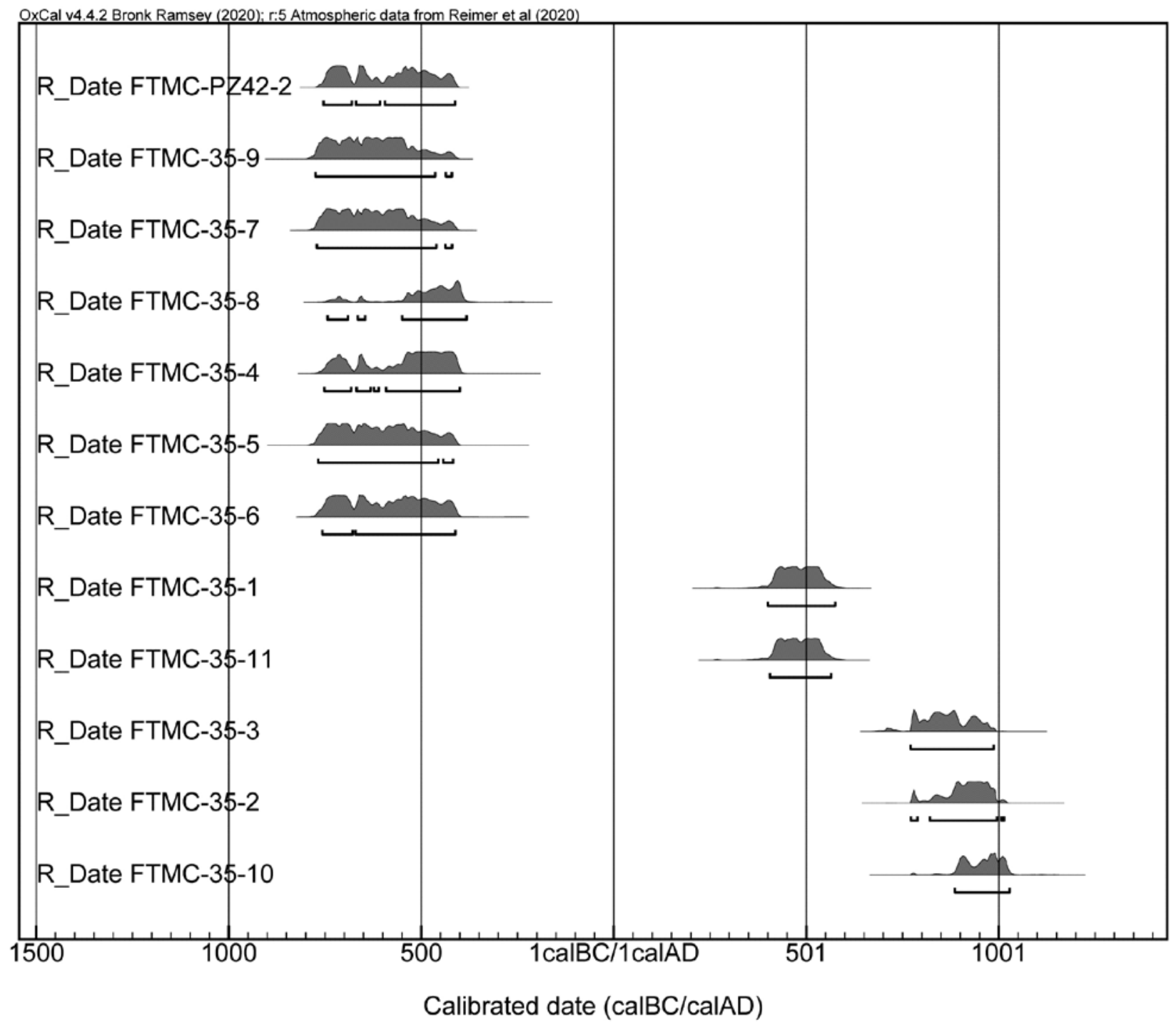

13 pav. Kalibruotų AMS ${ }^{14} \mathrm{C}$ datų diagrama. Parengè A. Simniškytè.

Magnetogramoje ties aikštelès $\mathrm{R}$ pakraščiu išryškejjusi anomalija ir zonduojant nustatyta antropogeninès kilmès sedimentų storymė prieš tyrimus buvo palaikyti užslinkusių ịtvirtinimų požymiu, tikètasi čia aptikti griovị. Atlikus tyrimus nustatyta, kad tai - ne griovio, bet tarp pylimo ir nuožulnaus aikštelès paleoreljefo (ties kv. AB/6-8) susidariusioje dubumoje akumuliuoti sedimentai (17 pav.). Visas dubumos turinys iš $65-130 \mathrm{~cm}$ gylio laikomas vienu 5-u kontekstu, nors radiniai jame ne vieno meto. Pagrindinę dalị sudarè šukès - 115 (per 700 g):
$30 \%$ - kruopètu, $21 \%$ - gludintu, $20 \%$ - brūkšniuotu, $19 \%$ - lygiu, $3 \%$ - grublètu paviršiumi, $3 \%$ žiestoji keramika (1 lentelè, 18 pav.). Pastarosios keramikos skeveldrų rasta tiek viršutinejje (70 ir $85 \mathrm{~cm}$ gylyje), tiek apatineje dubumos dalyje $(125 \mathrm{~cm}$ gylyje). Kiti radiniai - geležies šlako fragmentas ir kelios smulkios (vidutiniškai - vos po 1 g) gyvulių kaulų skeveldros, daugiausia avies ir ožkos (22 pav.). Kartu aptikti istorinių laikų radiniai - ir nearcheologiniai (vinis, stiklo duženos) - rodo gruntą šioje vietoje judinus gerokai vèlesniais laikais. 


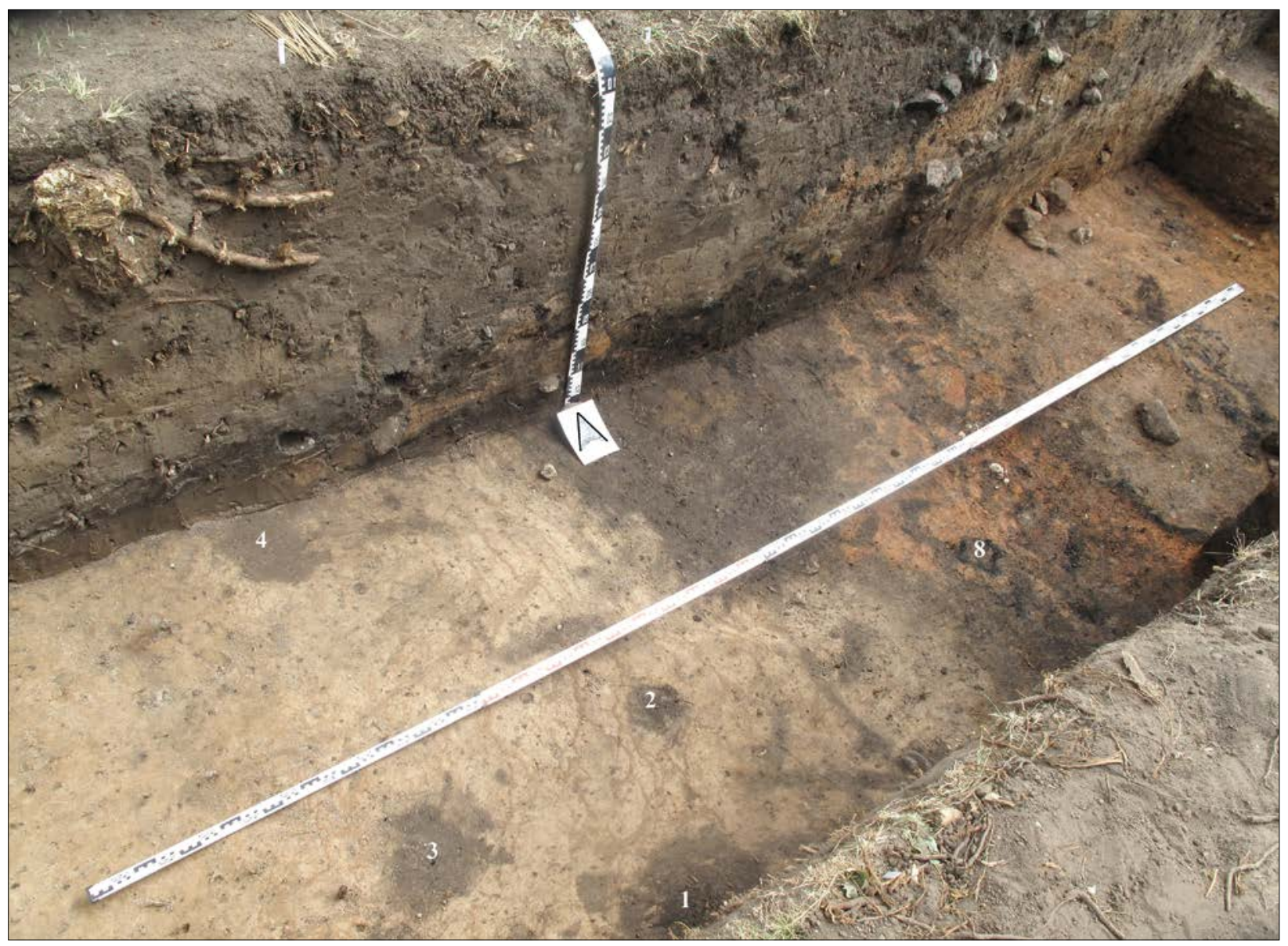

14 pav. Spėjamos stulpavietės centrinèje perkasos dalyje ir kultūrinio sluoksnio pèdsakai tarp pylimo ir nuožulnėjančio aikštelès paviršiaus. A. Simniškytès nuotr.

Galiausiai piliakalnio įtvirtinimus ir nelygumus užlygino iki $60 \mathrm{~cm}$ storio viršutinis dirvožemio sluoksnis (6-as kontekstas), jame vyravo paskutinių šimtmečių palikimas (smulkios vielutès, kamščiai, sagos, kelios sovietinių laikų monetos, lietuviški centai). Archeologinių radinių negausu - keliolika priešistorinių laikų lipdytinės keramikos šukių, dvi XVII a. pradžios monetos, smiltainio galąstuvèlis.

Archeologiniai radiniai. Iš viso suregistruota apie 230 radinių. Didžiausią dalị sudarè kerami$\mathrm{ka}-1532,4 \mathrm{~g}$, iš jų suregistruota 219 šukès (1354 g) (1 lentelè, 18 pav.). Dauguma - sienelių šukès, 28 pakraštèliai ir 4 dugneliai/priedugniai. Šukès smulkios, aptrupejusiais paviršiais. Dèl šukių fragmentiškumo indų dydžių ir proporcijų nustatyti neįmanoma.
Remiantis keliais didesniais fragmentais, teigtina, kad vienas indas galejęs būti su $19 \mathrm{~cm}$ skersmens anga, kito dugno skersmuo $-14 \mathrm{~cm}$.

Gausiausiai rasta keramikos brūkšniuotu paviršiumi - 88 šukès (iš jų 5 pakraštèliai ir 2 priedugniai) (19 pav.). Šukès smulkios ( $\left.\mathrm{x}^{-}-5,8 \mathrm{~g}, \mathrm{x}^{\sim}-3,8 \mathrm{~g}\right)$, 6-11 mm storio, daugiausia 7-8 mm, liesintos ịvairaus gausumo $2-5 \mathrm{~mm}$ dydžio mineralinèmis priemaišomis. Daugelio šukių brūkšniuotos abi pusès. Prie ankstyvos brūkšniuotosios keramikos, galbūt to paties meto, kaip ir ankstyvasis pylimas, galima priskirti keletą pakraštèlių beveik tiesiu kakleliu (19: 1 pav.), kelis priedugnius, platėjančius prie dugno (19: 5 pav.), netvarkingai ir negiliai brūkšniuotas šukes (19: 3 pav.). Keli indą su briauna primenantys 


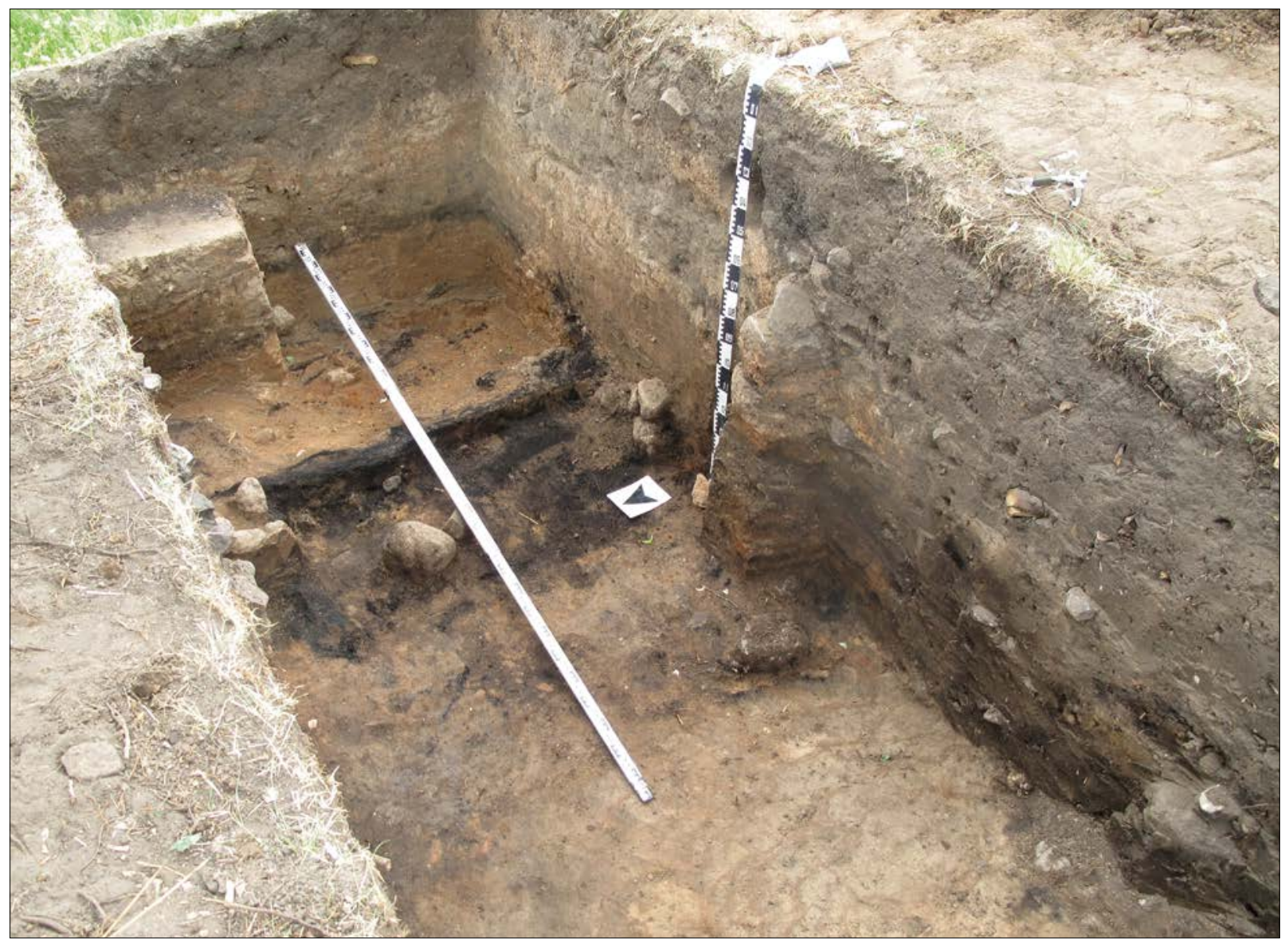

15 pav. Sudegusių medinių konstrukcijos liekanos (iš ŠV). Tolesniame plane - sudegusių kuolų konstrukcijos pėdsakai (1-as kontekstas), artimesniame - sudegę rąstai (2-as kontekstas). A. Simniškytés nuotr.

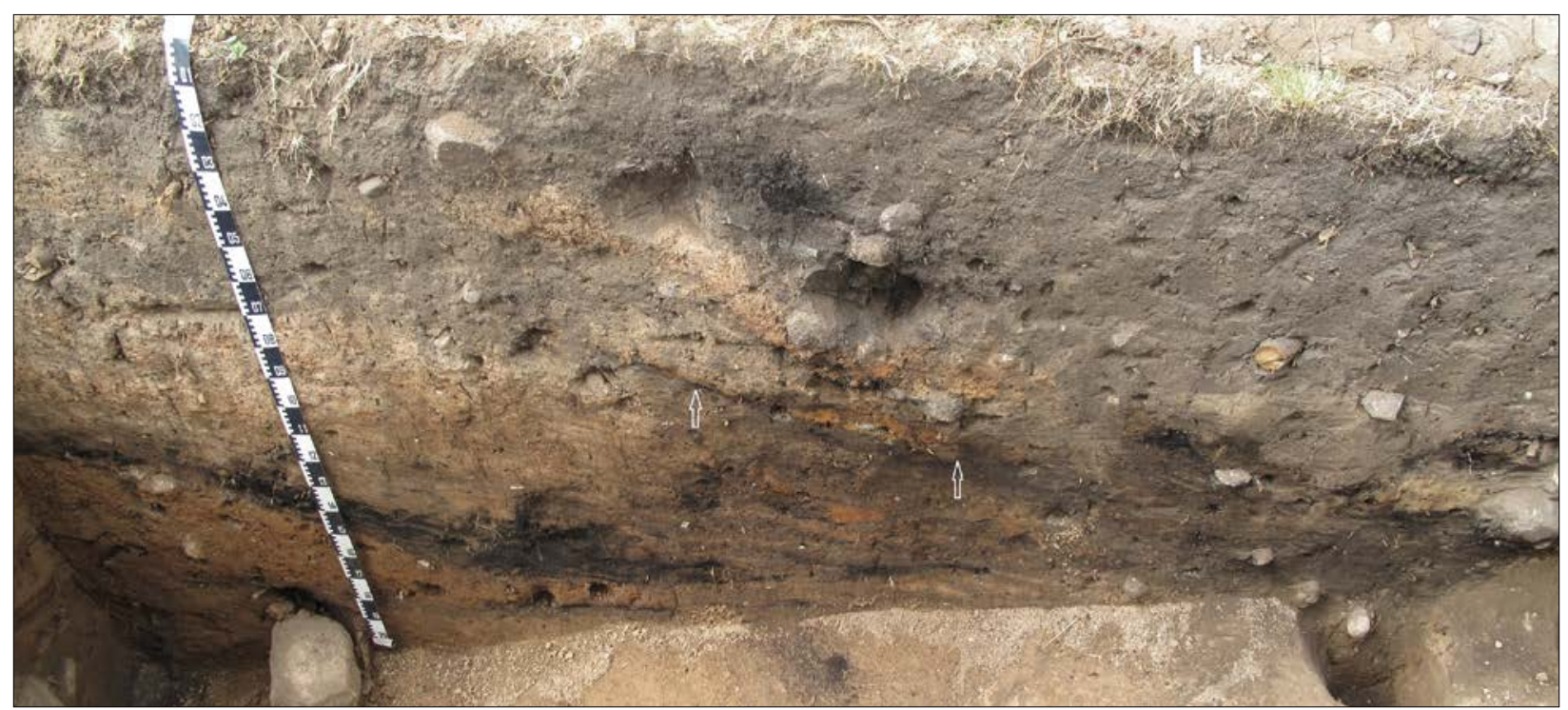

16 pav. Perkasos P sienelès pjūvio atkarpa. Rodyklèmis pažymètas degèsių sluoksnelis 3-io konteksto viršuje. A. Simniškytès nuotr. 


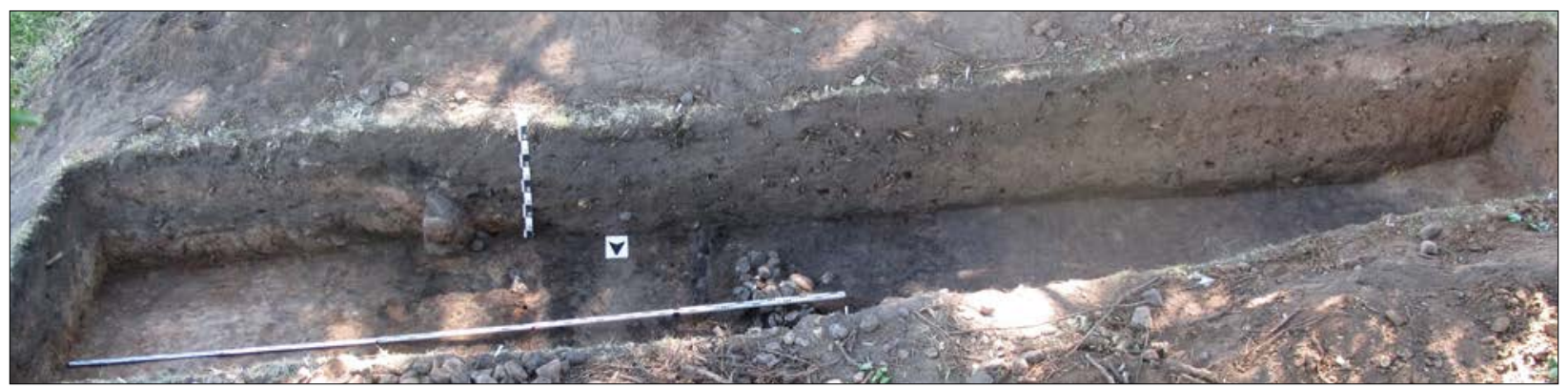

17 pav. Bendras perkasos vaizdas 1 m gylyje. Tarp pylimo ir aikštelès paleoreljefo susikaupę tamsūs sedimentai (5-as kontekstas), vaizdas iš Š. V perkasos gale matyti ryškejjantis 1-as objektas. A. Simniškytès nuotr.

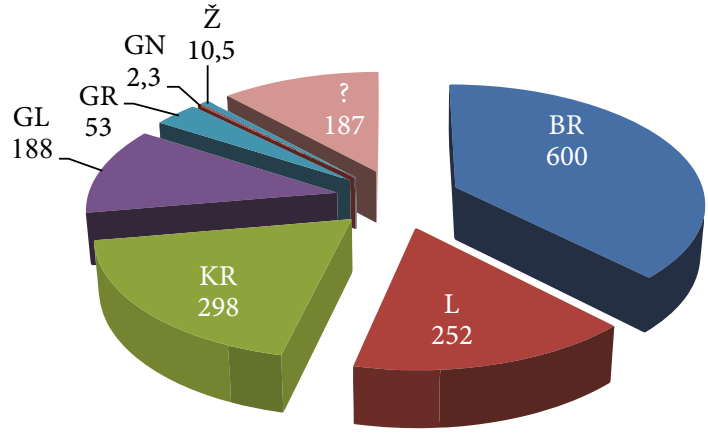

A

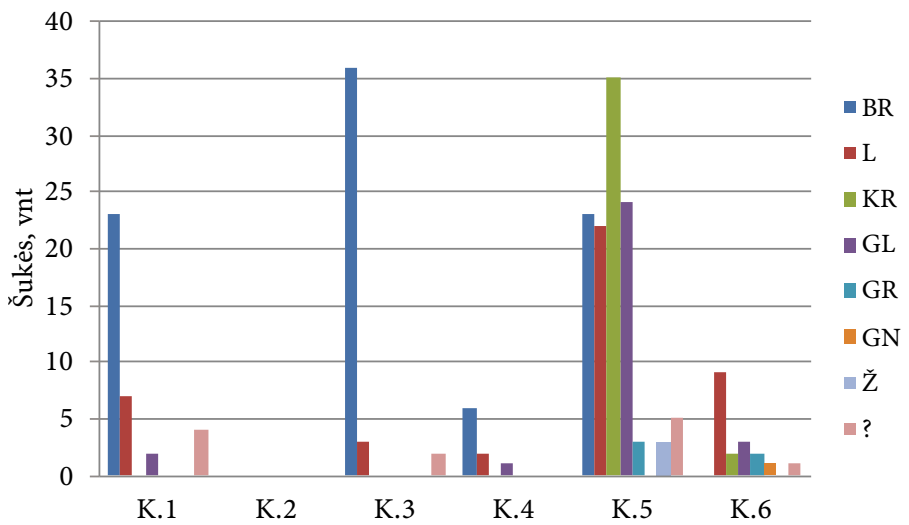

B

18 pav. Keramikos rūšių pasiskirstymas: A - pagal svorị (g); B - pagal šukių skaičių (K - tekste minimi kontekstai). Parenge் A. Simniškytè.

pakraštèlių fragmentai (19: 2 pav.), ryškiau, viena kryptimi brūkšniuotos šukès (19: 4 pav.) galètų būti laikomos vèlyvesnio etapo - erų sandūros brūkšniuotąja keramika. Tačiau apskritai smulkias sienelių šukes skirstyti ị ankstyvą ir vèlyvą fazę yra keblu, juolab jos aptiktos kartu. Brūkšniuotoji keramika buvo pagrindinè 1-ame ir 3-iame kontekstuose, su kitos rūšies keramika jos aptikta mišriame 5-ame kontekste.

Antra pagal gausą keramikos grupè - šukès lygiu paviršiumi - 43 (iš jų - 5 pakraštèliai ir 2 priedugniai). Jos nežymiai smulkesnès už brūkšniuotąją $\left(\mathrm{x}^{-}-5,7-\mathrm{g}, \mathrm{x}^{\sim}-3,2 \mathrm{~g}\right)$, itvairaus storio $(5-15 \mathrm{~mm})$, daugiausia $7 \mathrm{~mm}$. Molio masè liesinta ịvairaus gausumo ir dydžio (1-7 mm) mineralinėmis priemaišomis, smulkių priemaišų daugiau $\left(\mathrm{x}^{\sim}-2 \mathrm{~mm}\right)$. Dalis keramikos lygiu paviršiumi gali būti to paties meto, kaip ir brūkšniuotoji, o gal pasitaikè neužbrūkšniuotų šios keramikos fragmentų. Viena šukè puošta geometriniu ornamentu ir reprezentuoja antrai I tūkstantm. po Kr. pusei būdingus indus tiesiomis ị viršų platėjančiomis sienelèmis ir ị vidų kiek palenktu pakraštèliu (19: 7 pav.). Kelios tvirtesnio molio šukès su $<2 \mathrm{~mm}$ dydžio priemaišomis taip pat gali būti priskiriamos šiam laikotarpiui. Daugiausia keramikos lygiu paviršiumi rasta 5-ame kontekste.

Keramikos kruopètu paviršiumi suregistruota 37 šukès (iš juc - 3 pakraštèliai) (20: 1 pav.). Jos stambesnès ( $\left.\mathrm{x}^{-}-8,1 \mathrm{~g}, \mathrm{x}^{\sim}-5,4 \mathrm{~g}\right), 6-11 \mathrm{~mm}$ storio, dažniausiai - $9 \mathrm{~mm}$. Molio mase liesinta gausiomis ir stambokomis (3-8 mm, $\left.\mathrm{x}^{\sim}-5 \mathrm{~mm}\right)$ mineralinèmis priemaišomis. Nemaža dalis šukių gali būti vieno 


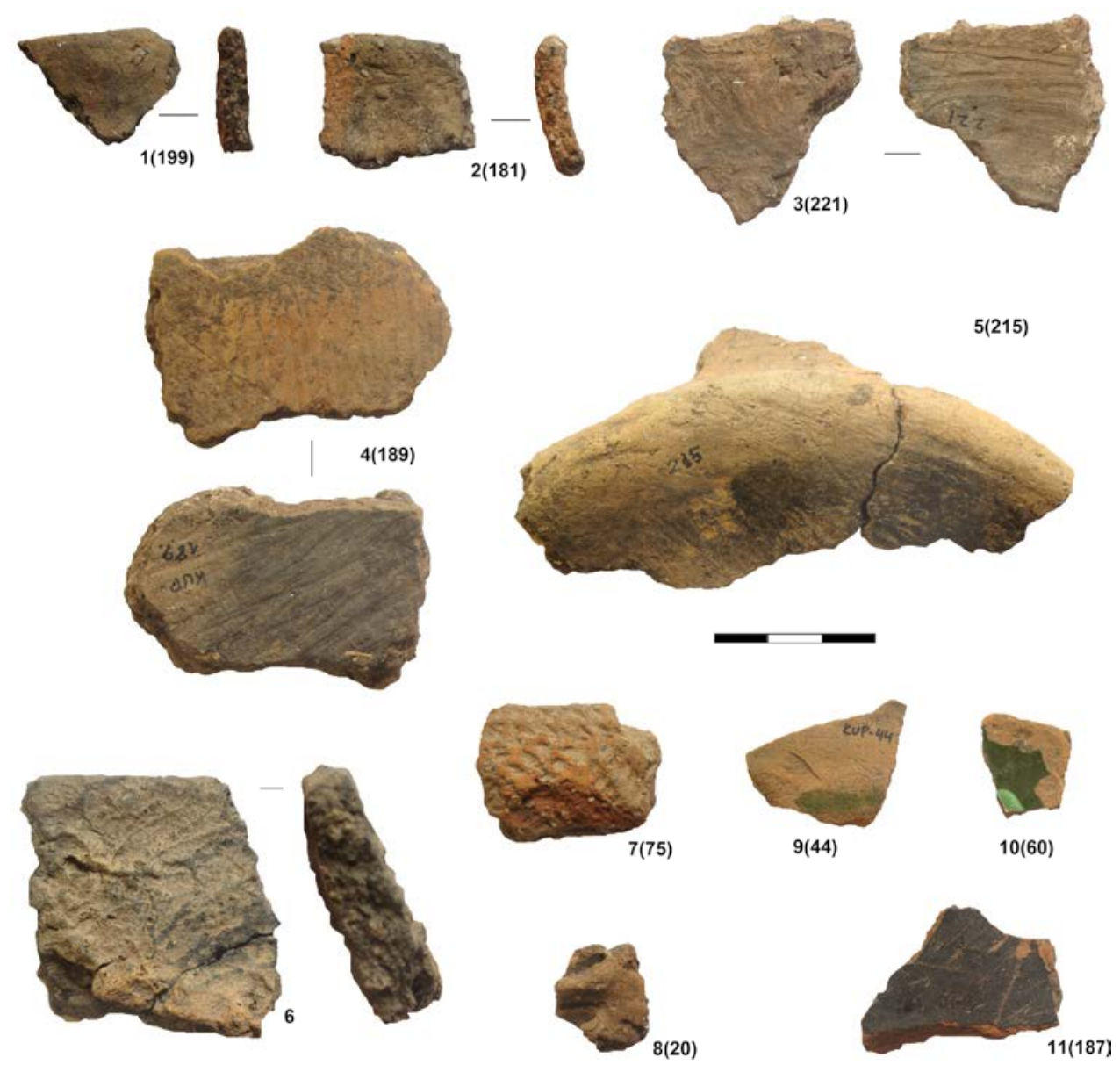

19 pav. Ivvairių laikotarpių keramika: 1-5 - šukès brūkšniuotu paviršiumi; 6 - šukè grublètu paviršiumi; 7 - pakraštelis, puoštas geometriniu ịspaudų ornamentu; 8 - šukè su gnaibymo elementais; 9-11 - žiestoji keramika su glazūra (skliausteliuose pateikti lauko Nr.). A. Simniškytés nuotr.

indo su 19-20 cm skersmens anga. Tai puodas su $5 \mathrm{~cm}$ žemiau pakraščio esančia briauna, aukščiau jos kaklelis tiesus, pakraštèlis atloštas ị išorę (20: 1 pav.). Kruopètumo sluoksnis plonas, molio masè sausa, su negausiomis $1-2 \mathrm{~mm}$ mineralinèmis priemaišomis. Lietuvoje ankstyviausia kruopètoji keramika datuojama antra I tūkstantm. pr. Kr. puse tai urnos iš Egliškių (Kretingos r.) ir Paveisininkų (Lazdijų r.) (Grigalavičienė 1995, p. 224). Ankstyvosios kruopètosios keramikos pavyzdžių rytinejje Lietuvos dalyje nedaug, pagal analogijas iš Kernavès Aukuro kalno (Širvintų r.), Bačkininkèlių piliakalnio (Prienų r.) papèdès, Aukštadvario piliakalnio (Trakų r.) ji datuojama erų sandūra (Vengalis 2007, p. 124). Beveik visa keramika kruopètu paviršiumi rasta 5-ame kontekste.

Keramikos gludintu paviršiumi suregistruota 30 šukių (iš jų - 12 pakraštėlių) (20: 2-9 pav.). Radiniai smulkoki ( $\left.\mathrm{x}^{-}-6,2, \mathrm{x}^{\sim}-4,7 \mathrm{~g}\right)$, storis 7-11 mm. Indų molio masė tanki, priemaišų plika akimi nematyti arba jos itin smulkios ( $\leq 1 \mathrm{~mm}$ ). Rasta juosvų, gelsvų ir rusvų šukių. Spalva priklausė nuo molio rūšies, išdegimo technologijos, o gludintajai keramikai dažnai taikyta redukcinè. Gludinti indai išsiskiria itin lygiu išoriniu sienelių paviršiumi, pagalbiniais įrankiais (oda, kaulu, akmeniu) nulygintu kartais iki blizgesio. Pagal analogijas žinoma, kad dažniausiai naudota briauninès formos gludintoji keramika su briauna 


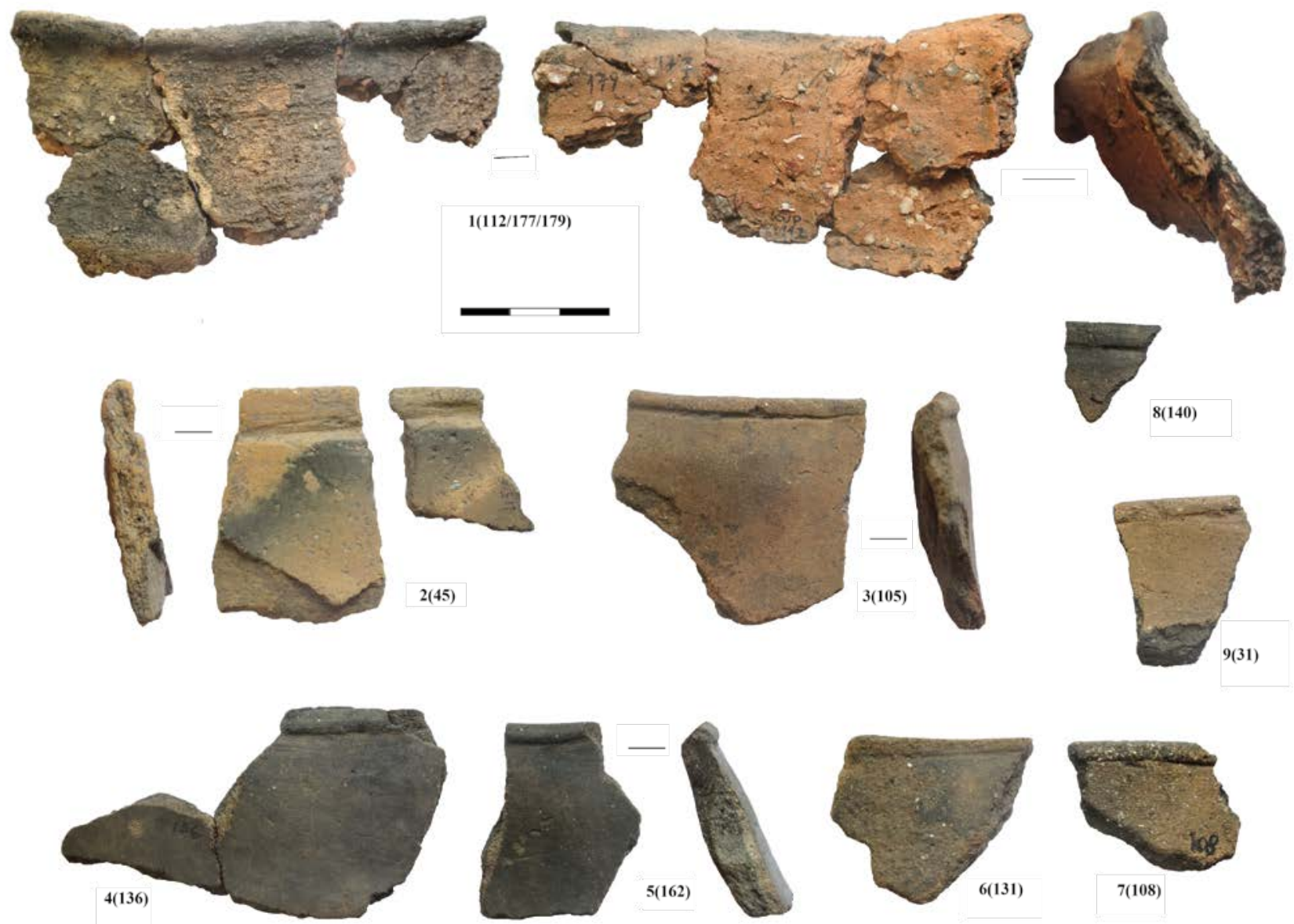

20 pav. Lipdytinè keramika kruopètu (1) ir gludintu paviršiumi (2-9) (skliausteliuose pateikti lauko Nr.). A. Simniškytės nuotr.

$2-5 \mathrm{~cm}$ žemiau pakraščio, aukščiau briaunos kakleliai palenkti ị vidų, tiesūs arba iggaubti.

Kupiškio piliakalnyje rastos šukès smulkios, išlikusios tik viršutinès kaklelių dalys; jų pakraštėlis prie pat angos buvęs kiek paplokštintas į išorę, kai nulipdytas puodas buvo apverstas ir pastatytas dugnu aukštyn. Vienas pakraštèlis išryškintas, prie angos įrèžus griovelị jau indui išdžiūvus (20: 2 pav.).

Lietuvoje ankstyviausi paviršiaus apdirbimo gludinant pavyzdžiai žinomi kaip antros I tūkstantm. pr. Kr. pusės kapų keramika V. Lietuvoje bei Užnemunèje ir siejami su Rytprūsių (Sembos) ir Vyslos žemupio keramika (Grigalavičienè 1995, p. 227-229). Lietuvos piliakalniuose jų rasta I tūkstantm. pr. Kr. pabaigos I tūkstantm. po Kr. pradžios sluoksniuose: Kernavès Aukuro Kalne, Rytų Lietuvoje (Luchtanas 1994) ar
Dapšiuose, Žemaitijoje (Daugudis 1989, p. 83). Kupiškyje beveik visa keramika gludintu paviršiumi rasta su kitų rūšių keramika 5-ame kontekste (2 lentelè).

Kitos rūšies lipdytinès keramikos rasta vos po vieną ar kelias šukes. Tai lipdytinè grublètu (5 vnt.) (19: 6 pav.) ir gnaibytu (1 vnt.) (19: 8 pav.) paviršiumi 5- ir 6-ame kontekstuose. Taip pat aptikti trys smulkūs istorinių laikų žiestosios keramikos fragmentai (19: 9-11 pav.): du iš jų puošti žalia glazūra, gali būti datuojami XVII-XIX, o ruda glazūra puošto koklio skeveldra - XVIII-XIX a.

Geležies šlakas. Centrinèje perkasos dalyje $110 \mathrm{~cm}$ gylyje aptiktas vienintelis geležies gavybą liudijantis radinys - geležies šlako gabalas, $9 \times 4,8 \times$ $2,1 \mathrm{~cm}, 125 \mathrm{~g}-5$-ame kontekste su ịvairių laikotarpių radiniais. 

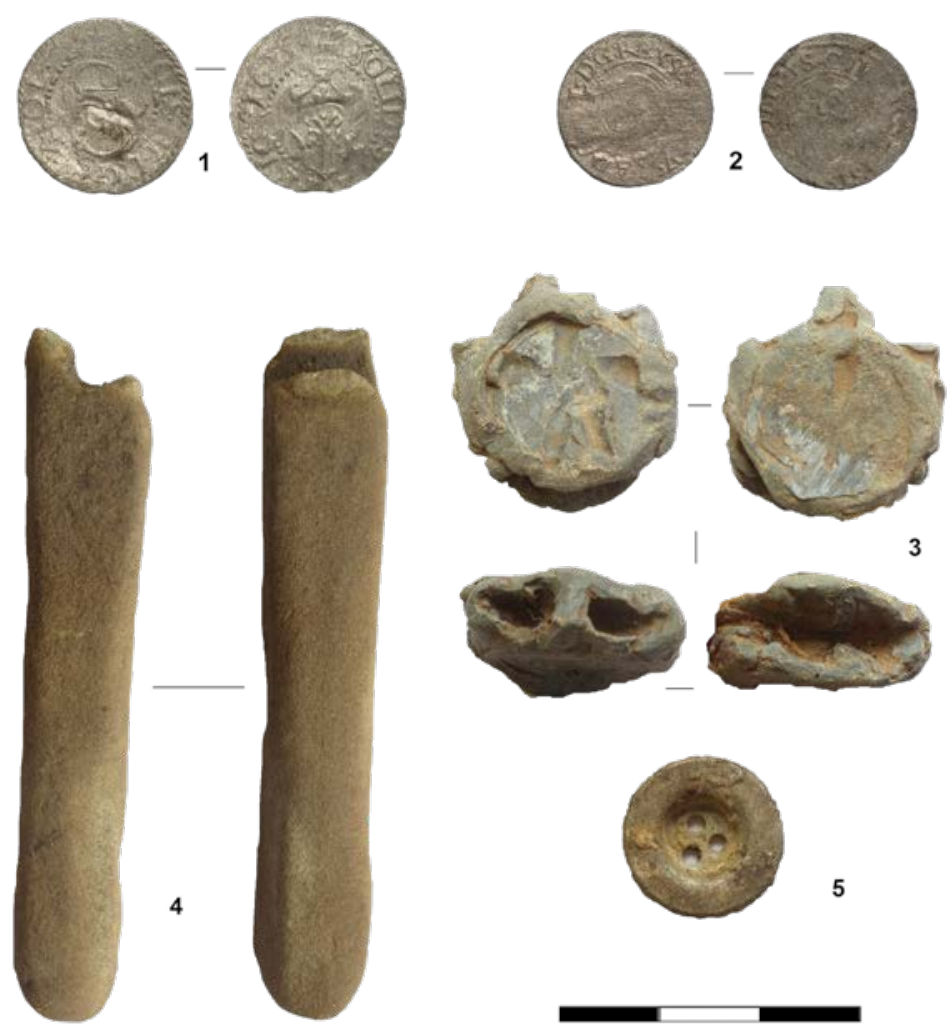

5

21 pav. Istorinių laikų radiniai: 1 - prasto sidabro Rygos šilingas, 1615 m. (Zigmantas III Vaza); 2 - prasto sidabro Rygos šilingas, tarp 1621 ir 1634 m. (Gustavas II Adolfas); 3 - švininè plomba; 4 - smiltainio galąstuvèlis; 5 - metalinė vokiškos uniformos saga. A. Simniškytès nuotr.

Monetos. Metalo detektoriumi žvalgant perkasos vietą, viršutiniame dirvožemio sluoksnyje (6-ame kontekste) rastos dvi archeologinę vertę turinčios monetos (21: 1, 2 pav.). Tai - prasto sidabro Rygoje nukaldinti XVII a. pradžios šilingai: vienas - Zigmanto III Vazos (nukaldintas 1615 m.), kitas - Gustavo II Adolfo (kaldintas tarp 1621 ir 1634 m.).

Galąstuvas. Ten pat $50 \mathrm{~cm}$ gylyje aptiktas ir smiltainio galąstuvèlis $-7,1 \mathrm{~cm}$ ilgio, $1,2 \times 1,1 \mathrm{~cm}$ apvalinto keturkampio pjūvio, $16 \mathrm{~g}$, su $0,5 \mathrm{~cm}$ išgręžta skylute viename gale (21: 4 pav.). Galąstuvų dažniausiai randama kapuose nuo pirmųjų m. e. amžių. XVXVII a. palaidojimuose tai gana dažna ịkapé, paprastai randama juosmens srityje - kaip ir buvo nešioti pritvirtinti prie diržo ar ịdėti ị kapšelị. Galąstuvèlio galvutè ties skylute buvo išlūžusi, dèl to jis, matyt, ir pamestas.
Plomba. Ten pat rasta $2,3 \times 2,3 \mathrm{~cm}, 23,4 \mathrm{~g}$ švininè (21: 3 pav.). Datuojama XIX a. pabaiga - XX a. viduriu.

Kiti radiniai. Ten pat, o tyrimų metu irgi pasitaikė XX a. radinių: smulkių vielučių, kamščių, sovietinių laikų monetų, lietuviškų centų, vokiškos uniformos saga (21: 5 pav.) (50 cm gylyje), kelios stiklo duženos $(85-95 \mathrm{~cm})$, vinis $(136 \mathrm{~cm})$.

\section{Zooarcheologiniai duomenys. Buvo ištirti} 69-i gyvūnų kaulų ir dantų fragmentai (297 g). Medžiaga išlikusi prastai, fragmentai smulkūs, erodavę, aptrupèję, tad identifikuota tiktai dalis jų (184 g), iš kurių beveik pusè - dantų. Dèl prasto išlikimo, kapojimo, pjovimo žymių beveik nematyti. 24 pavyzdžiai - naminių gyvulių (89\%): kiaulių $33 \%$; ožkų ir avių - $28 \%$, galvijų - $17 \%$, arklių $11 \%$. Dar 3 kaulai laukinių gyvūnų - elnių - liekanos (11\%). Kiaulių ir galvijų kaulų daugiausia 1-ame ir 
3-iame kontekstuose. Ožkų ir avių daugiau rasta 3-iame ir 5-ame, arklio ir elnio - 5- ir 6-ame kontekstuose (22 pav.).

Kiaulių amžius - apie 10 mèn. ir 1,8 m. leistų manyti, kad jos greičiausiai paskerstos atitinkamai prieš pirmąją ir antrąją gyvenimo žiemą ar jos pradžioje. Tai tradicinis ir dažniausiai pasitaikantis kiaulių skerdimo amžius ir laikas. Kitų gyvulių liekanos, turint galvoje amžių, negausios ir mažai informatyvios: avių ir ožkų - suaugusių individų, 2-4 m. gyvulių, arklių - jaunų (iki 2,5-3,5 m.); jie greičiausiai buvo suvartoti maistui (Piličiauskienė 2018).

Paleobotaniniai duomenys. Paleobotaniškai išanalizuoti 4-ių stulpaviečių $(2,3,4,7)$ mėginiai, jų tūris - 3600-9100 ml. Organikos, taigi ir augalų makroliekanų, labai nedaug. Išliko tik degusių augalų liekanų. Daugiausia tai medienos anglis, taip pat keletas augalų vaisių ir sèklų: stulpavieteje 3 rastai negausūs javų (Cerealia) ir galbūt lęšio (Lens) fragmentai; stulpavietėje 4 - nedidelis fragmentas javų grūdo; stulpavietèje 7 - miežio grūdas. Kartu aptiktas degusias branto, lipiko, liucernos, viksvos, bastutinių, baltosios balandos liekanas galima vertinti kaip šių kultūrų piktžoles (nors jos galèjo augti ir ne pasèliuose), o avietes, žemuoges, šermukšnius - kaip maistui naudotus išteklius ar natūraliai aplinkoje paplitusius augalus (Kisielienè 2018). Miežio grūdas datuotas 755-413 cal BC, šiam laikotarpiui greičiausiai priklausė ir kitų stulpaviečių paleobotaninis turinys, taip pat spejjamas lęšio fragmentas, kuris bùtų antras surastas atvejis I tūkstantm. pr. Kr. Lietuvos archeologinèje medžiagoje (Minkevičius et al. 2020).

\section{PILIAKALNIO APGYVENIMO ETAPAI}

Kupiškio piliakalnio tyrimų rezultatai iš esmès atitiko teorines prielaidas apie Sèlos krašto piliakalnių raidą, kartu pateikè gana netikètų duomenų apie piliakalnį. Prieš apgyvenimą kalva buvo visiškai kitokios formos nei dabar. Iš esmès prie to prisidejo vèlesnių laikų piliakalnio pertvarkymai, taigi ir vykę XX a. pradžioje: centrinejje aikštelès dalyje galèjo būti nugremžti kultūriniai sedimentai, kurie, perklostyti aikštelès pakraščiuose, visiškai paslèpė ankstesnes reljefiškas formas - pylimą kalvos pakraščiuose. Nustatyti keturi pylimo tvirtinimo ir gaisrų etapai. Pirmi du - antrame I tūkstantm. pr. Kr. ketvirtyje, trečias - I tūkstantm. po Kr. viduryje, ketvirtas - ketvirtame I tūkstantm. po Kr. ketvirtyje.

Kalva buvo apgyventa brūkšniuotosios keramikos kultūros laikotarpyje. Nors iki kasinèjimų pradžios duomenų apie ši metą neturèta, jo tikimybė buvo iškelta atlikus geocheminius grunto tyrimus ir nustačius reikšmingą $P$ ir OM padidejimą antropogeninès kilmès nuosėdų apačioje. $P$ ir organinių medžiagų padaugèjimas apatiniuose horizontuose galejo vykti kalvoje gyvenant, o tai atitiktų ankstyvąji piliakalnių raidos modelio etapą brūkšniuotosios keramikos kultūros laikotarpyje.

Pradejusiame kauptis kultūriniame sluoksnyje vyravusi brūkšniuotoji keramika yra tik labai preliminarus chronologinis kalvos apgyvenimo pradžios orientyras. Kalvose įkurtų gyvenviečių reiškinio pradžia Lietuvoje ir kaimyninèse šalyse datuojama maždaug II/I tūkstantm. pr. Kr. sandūra, kartais - kiek 
anksčiau ar vèliau (plačiau žr. Lang 2018; Podėnas 2019), tačiau kiekvieno konkretaus objekto chronologija priklauso nuo daugelio veiksnių: tyrimų apimčių, tyrinètos vietos, radinių, plokščiakalnių ${ }^{14} \mathrm{C}$ datų kalibracijos kreiveje ir pan. Kalbant apie ankstyvųjų piliakalnių datavimą reikètų akcentuoti radiokarboninių datų, neabejotinai susijusių su ịsikūrimu kalvoje, trūkumą. Ilgalaikio ir pakartotinio apgyvenimo eigoje susikaupè, susimaišè ir persiklojo nors kultūriškai ir vientisi, tačiau chronologiškai skirtingi epizodai. Imant mėginius radiokarboniniam datavimui tikimybe், kad datuojami ankstyviausi, tèra numanoma, o nustatytos seniausios datos ir laikomos apgyvenimo pradžia. Kelių ar net keliolikos mėginių datavimas nelems norimo rezultato, jei nepavyks nustatyti kontekstų sekos, o tai padaryti nestratifikuotam, ilgalaikiam objektui yra labai sudetinga.

Kupiškio piliakalnio apgyvenimas rekonstruotas pagal stratigrafinę itvirtinimų kontekstų seką. Ankstyviausios AMS datos rodo, kada preliminariai buvo suręsti, o tiksliau sudegè, pirmieji įtvirtinimai. Tai ìvyko antrame I tūkstantm. pr. Kr. kevirtyje, tačiau lieka neatsakytas klausimas, kaip greitai jie buvo suręsti: ar kalvą nusižiūrèjusi bendruomenè būsimos gyvenvietès projekte jau matė ją ittvirtintą, ar ịtvirtinta buvo tik po kurio laiko? Kultūrinis sluoksnis kalvos pirminiame paviršiuje nebuvo „švarus“ kontekstas nei radiokarboninių datų, nei radinių chronologijos prasme, jame aptikta vèlesnių laikotarpių intarpu. Archeologiniai radiniai buvo paplitę pylimo ribojamoje aikštelès dalyje, po sampilu jų nerasta. Teoriškai, jei būtų kurị laiką gyventa kalvoje be ìtvirtinimų, kultūrinis sluoksnis ir radiniai būtų paplitę tolygiau, o pakraščiuose netgi tankiau. Tai leistų manyti, kad pylimas atskyrè pirminị kalvos paviršių dar prieš pasklindant žmogaus veiklos atliekoms kalvoje. Kita vertus, buvo ištirtas tik labai nedidelis izoliuoto paviršiaus plotelis; pirminis paviršius čia išsiskyrè pilkšva spalva, kuri paprastai atsiranda esant smulkių su degimu susijusių medžiagų, sakykim, mikroskopinių angliukų. Vadinasi, kažkokios deginimo pèdsakus palikusios veiklos ar įvykio (gal natūralaus gaisro) būta ir iki ịrengiant pirmuosius ịtvirtinimus. Šio epizodo chronologija lieka nenustatyta.

Tarp VIII ir V a. pr. Kr. kalvoje įrengta akmenų, grunto ir medžio konstrukcija per tą laikotarpi bent kelis kartus degė ir vèl buvo atstatyta. Pirmieji ịtvirtinimai - nuožulniame aikštelès pakraštyje suręsta medinè užtvara, kurią tvirtino išlikęs $0,5 \mathrm{~m}$ aukščio sampilas iš lauko riedulių ir priesmèlio. Po pirmo gaisro konstrukciškai stabilesniu gruntu bei ąžuoliniais rąstais sutvirtintas pylimas neišvengè to paties likimo, tad vèliau dar kartą buvo rekonstruotas. Aukštinant pylimą gruntas galejjo būti kasamas čia pat, tokiu būdu formuojant griovị pylimo išorèje, dabartinio griovio vietoje.

Pirmuosius du ịtvirtinimų epizodus liudijančios AMS ${ }^{14} \mathrm{C}$ datos patenka ị Halštato suplokštëjimą ir yra 350 metų tikslumo, todèl neįmanoma tiksliau pasakyti, kada kilo gaisrai, kurios iš datuotų struktūrų yra vienalaikès, ir kaip greitai įtvirtinimai buvo atstatomi. Apdegę rąstai rasti dar nespejję sunykti ar būti išsklaidyti, todèl manytina, kad pylimas buvo rekonstruojamas gana greitai.

Pereinant iš subborealio ị subatlantị (apie 850 cal BC) vykę klimato pokyčiai - sumažèjęs saulès aktyvumas, drègnesnis klimatas ir pakilęs gruntinių vandenų lygis - galejo paskatinti gyventojus kurtis pakilesnèse vietose (van der Plicht 2004, p. 57). Itvirtinimų paskirtis siejama su saugojimusi nuo žvėrių ar siekiant aptverti ant kalvos laikomus gyvulius, tačiau dažniausiai jie suvokiami kaip bendruomenių konfliktų signalai galbūt dèl maisto atsargų, gyvulių, jų pašaro ar kito turto. Kupiškio piliakalnio ịtvirtinimai bei pakartotinis jų atnaujinimas rodo atkaklias pastangas šioje vietoje likti (arba ją užimti). Tačiau iš nedidelès apimties tyrimų rezultatų sunku nustatyti, ar mitybą ir kasdieną liudijantys pédsakai ir buvo siektina/saugotina vertybè. Čia nerasta netgi kaulo, rago ir akmens dirbinių, būdingų brūkšniuotosios keramikos kultūrai šiaurès rytų Lietuvoje. 
Ivairūs keramikos tipai rodo: šis piliakalnis nebuvo vieno periodo gyvenvietè. Iš bendro konteksto žinoma, kad erų sandūroje brūkšniuotosios keramikos formos keitèsi - labiau išryškinta jos briauna (Vengalis 2009). Atsiranda ir kruopètoji panašių briauninių formų keramika, vèliau brūkšniuotąją Rytų Lietuvoje keitè keramika grublètu (Vengalis 2007), Sèloje - lygiu paviršiumi (Simniškytè 2013, p. 85). II-III a. piliakalniai apleidžiami, todèl I tūkstantm. medžiagos jų aikštelèse rasta nedaug (Simniškytė 2013, p. 52-55).

Kupiškyje šiam tarpsniui būdingos medžiagos rasta 5-e kontekste - griovi primenančioje dubumoje: dominavo kruopètoji ir gludintoji keramika, kiek mažiau - lygiu ir brūkšniuotu paviršiumi, kelios šukès grublètosios, taip pat istorinių laikų žiestosios keramikos. Tokio turinio sedimentai galèjo susidaryti per gana trumpą laiką, bet vèliau nei datuojama medžiaga. Apskritai 5-o konteksto medžiaga gali būti vertinama labai apibendrintai, iš esmès ji tik rodo, kad kažkokia veikla piliakalnyje vyko ir erų sandūroje, tačiau to meto kultūrinio sluoksnio pėdsakų tirtoje vietoje nenustatyta.

Kaip žmonių veiklos vieta kalva funkcionavo ilgesnị laiką, tiesa, galbūt ne nuolat ir gal nebūtinai buvo gyvenama. I tūkstantm. vidurio - antros pusės radinių piliakalnyje nedaug, ir tai iš esmès atitinka bendrąją Sèlos piliakalnių raidą. Tačiau aptiktieji pèdsakai neleidžia teigti piliakalnị tuo metu buvus apleistą. Pirminiame kalvos paviršiuje rastas objektas 1 buvo datuotas V-VI a., netoliese jo rasta antrai I tūkstantm. po Kr. pusei būdinga šukè. Aukščiau slūgsantys sedimentai yra judinti, ir tai iš dalies galètų paaiškinti, kaip ji ten pateko. Vidinejje trečią kartą paaukštinto pylimo pašlaitèje rasta keramika beveik išimtinai tik brūkšniuotu paviršiumi rodo, kad ir šis etapas gali būti brūkšniuotosios keramikos kultūros laikų. Tačiau horizontą dengę degèsiai datuoti I tūkstantm. viduriu. Datą laikant patikima, reikštų, kad arba laikotarpyje prieš Kristų trečią kartą paaukštintas pylimas tarnavo gerokai ilgiau nei pirmais kartais, galbūt tam tikru laiku atstatant tik medinę dali, arba pylimo trečio etapo įtvirtinimai yra I tūkstantm. vidurio statinys, panaudojant ankstesnio laikotarpio kultūrinị sluoksnị su brūkšniuotosios keramikos šukèmis.

Turima duomenų, kad VI a. gaisras sunaikino gyvenvietę ir Kerelių piliakalnyje (Kupiškio r.) (Grigalavičienè 1992b, p. 97, 100). Moškènų piliakalnis (Rokiškio r.), remiantis aikštelès radiniais, buvo datuotas iki VII a. (Grigalavičienè 1995, p. 32). Iki V-VI/ VII a. datuojamas vidurinis Juodonių piliakalnio ir ankstyvasis papèdès gyvenvietės (Rokiškio r.) horizontas (Grigalavičienè 1992a, p. 51, 56; Simniškytė 2013, p. 84-85). Ivykių sinchroniškumas skirtinguose objektuose lieka tik hipotetinis jau vien dèl plataus datavimo. Tik su didele atsarga juos galima sieti su bendrakultūriniu kontekstu baltų pasaulyje. I tūkstantm. viduryje baltų gentys išgyveno žymų socialinių ir ūkinių permainų metą. Šiems procesams daugiausia ịtakos galejo turèti didysis tautų kraustymasis (375-550 m.), prasidejęs Juodosios jūros pakrantèse pasirodžius Azijos klajokliams hunams. Jų antpuoliai išjudino visą Romos imperijos ir barbarų pasaulį, ịvairias gentis ir jų sąjungas iveldami ị kelis šimtmečius trukusias kovas. Gaisrų pèdsakai Rytų ir Pietų Lietuvos piliakalniuose bei geležiniai ịtveriamieji tribriauniai strèlių antgaliai kartais siejami su Lietuvą galbūt kažkada pasiekusiais hunų reidais (Zabiela 1995, p. 49; Лухтан 1997) arba klajokliškus „huniškus“ ypatumus perèmusių gyventojų puolimais (Bitner-Wróblewska, Kontny 2006). Sèlos krašte tokių akivaizdžių konfliktų požymių nenustatyta, tačiau pastebimai mažiau laidojimo paminklų duomenų (Simniškytè 2013, p. 79-80). Vis dèlto šito nereikètų laikyti krašto ištuštejjimo požymiu, nors tokia galimybė gana ịtikima dèl laikotarpio charakteristikos. Kapų skaičius gali neturèti nieko bendra su demografine padètimi - priešingu atveju būtų sunku paaiškinti egzistavimą V-VI a. ịtvirtinimų, nes juos reikia įrengti, prižiūrèti ir ginti. Bent dalis tokių bendruomenių jau IV a. galëjo gyventi 
piliakalnių papėdėse. Kol kas žinoma ir plačiau tyrinèta tik viena to laikotarpio papèdès gyvenvietè Juodonyse (Grigalavičienė 1992a; Simniškytė 2002). Reikia tikètis, kad išsamūs papèdžių gyvenviečių tyrimai tik prasideda, o apgyvenimo raidos klausimai ateityje bus svarstomi remiantis žymiai gausesniais duomenimis.

Sunku ịvertinti, ar po I tūkstantm. vidurio gaisro Kupiškio piliakalnis buvo kurị laiką apleistas, bet antroje I tūkstantm. puseje jis - jau vèl ịtvirtintas, o VIII a. pabaigoje - X a. dar kartą degè. Ketvirtą kartą tvirtinant pylimą buvo panaudotas kultūrinis ankstesnių laikų sluoksnis su itin fragmentuota keramika. Tai, kad nerasta gerai datuojamos I tūkstantm. po Kr. pabaigai būdingos medžiagos, rodo - piliakalnio paskirtis ir tuomet nebuvo gyvenamoji, ir tai atitinka Sèlos piliakalnių modeli, pagal kuri žmonių veikla tuo metu telkèsi papèdèse. Kol kas neturima duomenų, ar sudegę ketvirto VIII a. ketvirčio - X a. ittvirtinimai žymi tik gynybinių ịrenginių, ar ir šalia gyvenusios bendruomenès baigtị. Apie daugelio Sèlos piliakalnių egzistavimą I tūkstantm. po Kr. sprendžiama ne tiek iš jų pačių, kiek iš gyvenviečių šalia jų medžiagos. Jei tokių nenustatyta ar jos netyrinètos, kaip, tarkim, ilgą laiką buvo Moškènų ar Kerelių piliakalnių atveju, remiantis vien piliakalnių medžiaga, teigiama, kad objektai VI ar VII a. buvo apleisti (Grigalavičienè 1992b; 1995, p. 33, 37). Nors Juodonių piliakalnio aikšteleje taip pat aptikti vos keli to meto radiniai, tyrinèjant papèdès gyvenvietę, nustatyta, kad žmonių veikla telkèsi būtent čia (Grigalavičienė 1992a; Simniškytė 2002). Atlikus tyrimus Moškėnų piliakalnio aplinkoje, nustatyta, kad gyvenvietė gyvavo ilgiau nei „apleistas“ piliakalnis - kultūrinis sluoksnis papèdeje datuojamas I tūkstantm. viduriu - antra puse (Kavaliauskas 2014). Žvalgant kol kas netyrinètą Kerelių piliakalnio papèdę rastos dvi X a. apyrankès papildo antros I tūkstantm. pusès - II tūkstantm. pradžios atsitiktinių radinių kolekciją ir galètų būti vèlyvesnès gyvenvietès nei datuojamas piliakalnis požymis (Simniškytė 2013, p. 138-139). Žmonėms gyvenant netoliese, negalejo likti nuošalyje ir kalva, tačiau tikroji paskirtis (gynyba, saugumas, prestižas ar pan.) lieka nenustatyta. Kupiškio piliakalnis kol kas yra vienintelis Sèlos regione, kurio funkcionavimas I tūkstantm. pabaigoje remiasi jo įtvirtinimų radiokarboninemis datomis. Kol kas nèra galimybių šių duomenų palyginti su duomenimis iš šalia piliakalnio lokalizuojamos gyvenvietès - jos tyrimai dar laukia savo eilès.

Tyrinètoje vietoje VIII-X a. yra paskutinis tarpsnis piliakalnyje priešistoriniame laikotarpyje. II tūkstantm. pradžios pèdsakų neaptikta, todèl nèra ir pagrindo svarstyti piliakalnio svarbą krašto apgyvenimui. Labiau viduramžiams būdingi ịtvirtinimai ir kasinejjimų rezultatai byloja apie skirtingus laikus. Tai - ne klaida ar neatitikimas, nes išoriniai įtvirtinimai nebuvo tyrinèti. Lieka nenustatyta, kada piliakalnio kalva buvo apjuosta iki dabar matomu griovio ir pylimo žiedu. Istorinių laikų radiniai nèra tiesiogiai susiję su gyvenimu piliakalnyje, tačiau rodo dvaro ir augančio miestelio bendruomenès gyvenimo ypatumus. Tai liudija paviršiuje aptiktos dvi XVII a. pradžios monetos, galbūt to paties laiko smiltainio galąstuvèlis, taip pat keli žiestosios keramikos fragmentai. Keli elnių kaulai aptikti viršutiniame dirvožemio sluoksnyje (6-ame kontekste) ir gali būti susiję ne su priešistorinès bendruomenės ekonomika, bet liudyti vẻlesnių laikų pramogas, pvz., medžioklę. 1596 m. Kupiškio seniūnijos valstiečių ir miestiečių skunde rašyta: Kupiškio dvaro pareigūnai seniūnijos miškuose medžiodavo, dvare buvo medžioklinių šunų, taip pat sakalų (Totoris 2016). Šalia augančio miestelio stūksantis piliakalnis buvo nuolat lankomas ir vèliau. Kai kurie vèlyvi daiktai (stiklo duženos, keramikos šukès, vinis) buvo prasiskverbę gana giliai, ir gali būti bioturbacijų, perkasimų, lyginamo piliakalnio paviršiaus ir i pakraščius suslinkusio sluoksnio pasekmè.

Tyrimai suteikė naujos informacijos apie piliakalnị, tačiau toli gražu jie nèra galutinis taškas šio 
objekto pažinimui. Tiek išorinių ịtvirtinimų, tiek papèdès gyvenvietès tyrimai ateityje galètų praplèsti ir patikslinti žinias apie piliakalnị bei apie Kupiškio apylinkių apgyvenimą ir svarbą priešistorinèse ir ankstyvosiose valstybès struktūrose.

\section{IŠVADOS}

2017-2018 m. Kupiškio piliakalnyje vyko tarpdisciplininiai tyrimai: padaryta 150 gręžinių, atlikti geofizikiniai aikštelès matavimai, laboratoriniai grunto ir archeologinès medžiagos mèginių tyrimai bei ištirta $20 \mathrm{~m}^{2}$.

Tyrimų rezultatai iš esmès parėmè teorines prielaidas apie Sèlos krašto piliakalnių raidą, kartu pateikè gana netikètų duomenų apie piliakalnị. Pirminè kalvos forma buvo visiškai kitokia, nei matoma dabar. Kultūrinio sluoksnio aikštelès viduryje nerasta. Jis buvo nugremžtas piliakalnị pertvarkant vèliau. Perklostyti antropogeniniai sedimentai aikštelès pakraščiuose pakeitė natūralios kalvos formas ir visiškai paslèpé reljefinius itvirtinimus, kurių prieš tyrimus nebuvo matyti $2 \mathrm{~m}$ aukščio pylimą.

Pasitvirtino geocheminių grunto tyrimų pagrindu iškelta prognozè, kad kalva apgyventa dar I tūkstantm. pr. Kristų. VIII-V a. pr. Kr. padaryta akmenų, grunto ir medžio konstrukcija per tą laikotarpi bent kelis kartus degè ir vèl buvo atstatyta. Radiniai rodo piliakalnyje gyvenus ir erų sandūroje, tačiau to meto kultūrinio sluoksnio ar įtvirtinimų nenustatyta. I tūkstantm. po Kr. piliakalnis galejo buvo naudojamas kilus pavojui, ugnis piliakalnio itvirtinimus naikino V-VI ir VIII-X a. Vèlesnių laikų pèdsakų tiriant neaptikta.

\section{ŠALTINIŲ IR LITERATŪROS SĄRAŠAS}

Aston, M. A., Martin, M. H., Jackson, A. W., 1998. The use of heavy metal soil analysis for archaeological surveying. Chemosphere, 37, 465-477.
Baliński, M., Lipiński, T., 1846. Starožytna Polska pod względem historycznym, geografycznym i statistycznym opisana przez Michała Balińskiego i Tymoteusza Lipińskiego, III. Warszawa: nakład i druk S. Orgelbranda Księgarza.

Baliulis, A., 1997. Iš Kupiškio ir apylinkių praeities. In: Merkys, V. ir kt., red. Kupiškio kraštas. Vilnius: Vilspa, 48-137.

Baranauskas, T., sud., 2015. Sèlos aktai. Acta Seloniae. Joniškis: Simkala.

Baubonis, Z., Zabiela, G. 2005. Lietuvos piliakalniai. Atlasas, I. Vilnius: LR Krašto apsaugos ministerija.

Bitner-Wróblewska, A., Kontny, B., 2006. Controversy about three-leaf arrowheads from Lithuania. Archaeologia Lituana, 7, 104-122.

Bronk Ramsey, C., 1998. Probability and dating. Radiocarbon, 40 (1), 461-474.

Bronk Ramsey, C., 2009. Bayesian analysis of radio-carbon dates. Radiocarbon, 51 (1), 337-360.

Ciglis, J., 2002. Senās Sēlijas vēsturiskās ǵeogrāfijas problēmas. Latvija arheolog̣ija pētijumi un problèmas, 8, 9-25.

Clark, A., 1990. Seeing Beneath the Soil: Prospecting Methods in Archaeology. New York: Routledge.

Daugudis, V., 1989. Pirmojo tūks pr. m. e. šiaurès Žemaitijos piliakalniai (3. Radiniai). Lietuvos TSR mokslu akademijos darbai, A serija, 1(106), 74-88.

Daugudis, V., Tebelškis, P., 1997. Iš seniausios kupiškėnų krašto praeities. In: Merkys, V. ir kt., red. Kupiškio kraštas. Vilnius: Vilspa, 13-35.

Dearing, J., 1994. Environmental magnetic susceptibility: using the Bartington system. Bartington Instruments. London.

Elisonas, J., 1925. Archeologinių ir šiaip ịdomių, tiek Panevėžio apskrities, tiek kitų artimų apylinkių, vietų sąrašas, kurị yra surinkę Panevèžio valstybinès gimnazijos mokiniai. Švietimo darbas, 5, 434-458.

Grigalavičienè, E., 1992a. Juodonių piliakalnis ir gyvenvietè. Lietuvos archeologija, 9, 41-91. 
Grigalavičienė, E., 1992b. Kerelių piliakalnis. Lietuvos archeologija, 8, 85-104.

Grigalavičienè, E., 1995. Žalvario ir ankstyvasis geležies amžius Lietuvoje. Vilnius: Mokslo ir enciklopedijų l-kla.

Holliday, V. T., Gartner, W. G., 2007. Methods of soil $\mathrm{P}$ analysis in archaeology. Journal of Archaeological Science, 34, 301-333.

Kavaliauskas, A., 2014. Moškènų piliakalnis ir papèdès gyvenvietè. ATL 2013 metais, 64-68.

Kisielienė, D., 2018. Mèginių karpologinès analizès ataskaita. In: Simniškytè, A. Kupiškio, Aukštupènu piliakalnio su gyvenviete (23819), Kupiškio r. sav., Kupiškio sen., Aukštupènu k., 2018 m. detaliuju archeologiniu tyrimu ataskaita. LIIR, f. 1, b. 8902.

Krzywicki, L., 1906. Żmudz starożytna. Dawni Żmudzini $i$ ich warownie. Warszawa: Księgarnia Polska.

Kulikauskas, P., 1982. Užnemunès piliakalniai IXIII amžiuje. Vilnius: Mokslas.

Kviklys, B., 1965. Mūsu Lietuva, 2. Boston (Mass.): Lietuvių enciklopedijos leidykla.

Lietuvos, 1975. Lietuvos TSR archeologijos atlasas. Piliakalniai. II. Vilnius: Mokslas.

Lang, V., 2018. Fortified settlements in the Eastern Baltic: from earlier research to new interpretations. Archaeologia Lituana, 19, 13-33.

Luchtanas, A., 1992. Rytų Lietuva I tūkst. pr. m. e. Lietuvos archeologija, 8, 56-85.

Luchtanas, A., 1994. „Aukuro kalno“ piliakalnio Kernaveje tyrinejimai. ATL 1992-1993 metais, 50-53.

Matulionis, P., 1921. Kupiškio pilekalnis. Mūsų senove, 1/2, 77-78.

Minkevičius, K., Podènas, V., Urbonaitè-Ubė, M., Ubis, E., Kisielienè, D., 2020. New evidence on the southeast Baltic Late Bronze Age agrarian intensification and the earliest AMS dates of Lens culinaris and Vicia faba. Vegetation History and Archaeobotany, 29(3), 327-338.

Miškinis, A., 2009. Vidurio Lietuvos miestai ir miesteliai: monografija. Vilnius: Savastis.
Nezabitauskas, A., 1964. Kupiškio pilies kalnas. Komunizmo keliu (Kupiškis), 1964, bal. 28.

Nezabitauskas, A., 1968. Aukštupènai. Komunizmo keliu (Kupiškis), 1968, geg. 18.

Paulauskas, H., 1979. Kupiškènų kraštas. Vilnius: Mintis.

Peseckas, K., 2018. Medienos rūšys. In: Simniškytè, A. Kupiškio, Aukštupènu piliakalnio su gyvenviete (23819), Kupiškio r. sav., Kupiškio sen., Aukštupènu k., $2018 \mathrm{~m}$. detaliujų archeologinių tyrimu ataskaita. LIIR, f. 1, b. 8902.

Petrulienè, A., 2009. Aukštupènu piliakalnio (23819) rekonstruojamos teritorijos archeologiniai žvalgomieji tyrinejimai 2009 m. ataskaita. LIIR, f. 1, b. 5226 .

Piličiauskienè, G., 2018. Zooarcheologinių tyrimų rezultatai. In: Simniškytè, A. Kupiškio, Aukštupèny piliakalnio su gyvenviete (23819), Kupiškio r. sav., Kupiškio sen., Aukštupènu k., 2018 m. detaliųju archeologiniu tyrimu ataskaita. LIIR, f. 1, b. 8902.

Plicht, J. van der, 2004. Radiocarbon, the calibration curve and scythian chronology. In: Scott, E. M., Alekseev, A.Y., Zaitseva, G., eds. Impact of the Environment on Human Migration in Eurasia. Proceedings of the NATO Advanced Research Workshop, held in St. Petersburg, 15-18 November 2003, 45-61.

Podenas, V., 2019. Emergence of hilltop settlements in the southern Baltic: new AMS ${ }^{14} \mathrm{C}$ dates from Lithuania and revised chronology. Radiocarbon, 62(2), 361-377.

Reimer, P., Austin, W., Bard, E., Bayliss, A., Blackwell, P., Bronk Ramsey, C., Butzin, M., Cheng, H., Edwards, R., Friedrich, M., Grootes, P., Guilderson, T., Hajdas, I., Heaton, T., Hogg, A., Hughen, K., Kromer, B., Manning, S., Muscheler, R., Palmer, J., Pearson, C., van der Plicht, J., Reimer, R., Richards, D., Scott, E., Southon, J., Turney, C., Wacker, L., Adolphi, F., Büntgen, U., Capano, M., Fahrni, S., Fogtmann-Schulz, A., Friedrich, R., Köhler, P., Kudsk, S., Miyake, F., Olsen, J., Reinig, F., Sakamoto, M., Sookdeo, A., Talamo, S., 
2020. The IntCal20 Northern Hemisphere radiocarbon age calibration curve $(0-55 \mathrm{cal} \mathrm{kBP})$. Radiocarbon, 62(4), 725-757.

Salisbury, R. B., 2016. Soilscapes in archaeology. Settlement and Social Organization in the Neolithic of the Great Hungarian Plain. Budapest: Archaeolingua.

Simniškytè, A., 2002. Juodonių piliakalnio gyvenvietè. Chronologiniai ir struktūriniai pokyčiai. Archaeologia Lituana, 3, 137-156.

Simniškytè, A., 2005. Sèlos kraštas VI/VIIXIII/X IV a.: teritorinè struktūra ir hierarchija. Lietuvos archeologija, 27, 29-48.

Simniškytè, A., 2013. Geležies amžius Sèloje. Vilnius: Diemedis.

Simniškytè, A., Vengalis, R., 2018. Kupiškio piliakalnis. ATL 2017 metais, 106-109.

Tarasenka, P., 1928. Lietuvos archeologijos medžiaga. Kaunas: Švietimo ministerijos Knygų leidimo komisija.

Tarasenka, P., 1956. Lietuvos piliakalniai. Vilnius: Valstybinè politinès ir mokslinès literatūros leidykla.

Totorytè-Pustovaitienè, A., 2018. Kupiškio krašto archeologinès ir mitologinès vertybès. Utena: Utenos Indra.

Totoris, A., 2016. Kupiškio seniūnija XVI-XIX a. In: Jonušytè, A., sud. Kupiškis: naujausi moksliniai lokaliniai tyrimai. Vilnius: Versmè, 137-186.

Užgalis, M., 2018. Lamatos piliakalniai kultūrinio kraštovaizdžio kaitos kontekste. Archaeologia Lituana, 19, 141-153.

Vaitkevičius, V., Vaitkevičienė, D. 2011. Broliai milžiniai. In: Vaitkevičius, V., Vaitkevičienè, D., Lietuva: 101 legendine vieta. Vilnius: Alma littera.

Valanczauskas, M., 1891. Pasakojimas Antano Tretininko. Plymouth, Pa.: J. Paukszczio sp.

Vengalis, R., 2007. Grublètoji keramika Rytų Lietuvoje. Lietuvos archeologija, 32, 105-132.

Vengalis, R., 2009. Rytu Lietuvos gyvenvietes I-XII a. Daktaro disertacija. Vilniaus universiteto leidykla.
Vengalis, R., 2017. Geofizikiniai žvalgymai. In: Simniškytè, A. Kupiškio, Aukštupènu piliakalnio su gyvenviete (23819), Kupiškio r. sav., Kupiškio sen., Aukštupenų k., 2017 m. archeologinių žvalgymu ataskaita. LIIR, f. 1, b. 8902.

Vitkūnas, M., Zabiela, G., 2017. Baltu piliakalniai: nežinomas paveldas. Vinius: Lietuvos archeologijos draugija.

Wilson, C. A., Davidsson, D. A., Cresser, M. S., 2008. Multi-element soil analysis: an assessment of its potential as an aid to archaeological interpretation. Journal of Archaeological Science 35, 412-424.

Zabiela, G., 1995. Lietuvos medines pilys. Vilnius: Diemedis.

Zabiela, G., 2003. Lietuvos piliakalniai: tyrinejjimų aspektas. Lietuvos archeologija, 24, 33-56.

Zabiela, G., 2005. Piliakalniai - seniausieji Lietuvos gynybiniai itvirtinimai. In: Baubonis, Z., Zabiela, G., sud. Lietuvos piliakalniai. Atlasas, I. Vilnius: LR Krašto apsaugos ministerija, 4-21.

Zabiela, G., 2016. Kupiškio valsčiaus archeologija. In: Jonušytè, A., sud. Kupiškis: naujausi moksliniai lokaliniai tyrimai. Vilnius: Versmè, 120-136.

Žulkus, V., Jarockis, R., 2013. Vikingu laikai ir ikivalstybinis laikotarpis (Lietuvos archeologija. T. 4). Klaipèdos universiteto leidykla.

Гуковский, К., 1890. Вилкомирский уезд. Ковна.

Кживицкий, Л., 1909. Жмудские пилькалнисы. Известия Императорской археологической коммиссии. Санкт-Петербург. Выпуск 29, 82-129.

Лухтан, А., 1997. Война V века в Литве. Гістарычна-археалагічны зборник, 11, 15-20.

Покровский, Ф. В., 1899. Археологчческая карта Ковенской губернии. Вильна.

\section{SANTRUMPOS}

ATL - Archeologiniai tyrinèjimai Lietuvoje

LIIR - Lietuvos istorijos instituto Rankraštynas

VAK - Valstybės archeologijos komisijos medžiaga. Saugoma Kultūros paveldo centro archyve. 


\title{
HILLFORT OF KUPIŠKIS (AUKŠTUPĖNAI): THEORETICAL ASSUMPTIONS AND INVESTIGATION RESULTS
}

\author{
Andra Simniškytè
}

\section{Summary}

The hillfort of Kupiškis (Aukštupėnai) has never been investigated before but was regarded by many researchers as a former location of a wooden castle, used for defence during the attacks of the Teutonic Order (figs. 1-3). Interdisciplinary investigations were conducted in several stages between the years 2017 and 2018. At the beginning of research works, a number of assumptions were considered in regards to the development and role of the hillfort. The theoretical backbone for these ideas was based on the conclusions obtained through consideration of all the previously collected data regarding the cultural development within the Selonian region. These conclusions were further used to outline a preliminary model of development for the Selonian hillforts. The validity of the preliminary model has not been checked yet against the newly obtained data. A important part of this model was allocated for the consideration of the possible significance of Kupiškis Hillfort during the beginning of the 2 nd millennium $\mathrm{AD}$ and wooden castle's role in view of the attacks by the Teutonic Order. The hypothesis of the hill being settled during the 1st millennium BC arose after the geochemical study of the soil conducted during the first stage of investigations. No data related to the said period was known prior to this study. This article aims to present the results of the 2017-2018 investigations and to evaluate whether the aboveoutlined assumptions can be confirmed as correct.

The first stage of investigations was conducted in 2017 and involved geoarchaeological as well as a geophysical survey of the hillfort. The aim of these surveys was to evaluate the degree of preservation of the cultural layer, its thickness and extent, as well as to locate prospective areas for excavations and to collect soil samples for geochemical analysis. During the survey, a total of 150 boreholes were made (figs. 4-5), around 400 soil samples were collected for geochemical analysis (properties such as magnetic susceptibility (MS), organic matter (OM) and phosphorus $(P)$ were measured). Furthermore, a geophysical survey was conducted, which involved the use of ground-penetrating radar and magnetometer (figs. 6-7). During the second stage of investigations, archaeological excavations of a $20 \mathrm{~m}^{2}$ trench were conducted to verify chronology of the hillfort, its occupational sequence, and to collect data related to farming, diet, and lifestyle. The material discovered during excavations was analysed through the application of the AMS ${ }^{14} \mathrm{C}$ method, as well as paleobotanical, paleozoological and anthracological studies.

Although the obtained results corresponded with the theoretical model of Selonian hillforts, new and unexpected details about the structure of the hillfort were also revealed. Later reconstructions of the hillfort contributed to the radical change of the hill's shape. During the rebuilding works, cultural horizons were scraped off; thus even the level of the natural layers in the centre of the hilltop was lowered. Moreover, cultural and geological sediments were mixed and used to accumulated on the edges of the hilltop (Fig. 5), as a result, concealing the former shape of the relief (a former rampart located on the edges of the hill was only identified after the investigations). Four stages of the hillfort's reinforcement works and fires were ascertained. The first two stages were dated to the second quarter of the 1st millennium 
$\mathrm{BC}$; the third - to the middle of the 1st millennium $\mathrm{AD}$; the fourth, and the last stage, was dated to the fourth quarter of the 1st millennium AD (Table 2; figs. 9-11, 13).

An increase in the amount of phosphorus and organic matter was detected in the lower part of anthropogenic sediments (Fig. 8), indicating a settlement horizon on the hill. Theoretically, the presence of a settlement horizon corresponded to the early phase of the hillfort development model and was confirmed by the discovery of a Brushed Pottery culture horizon in the buried surface layer of the hill (Context 1) (Table 1; figs. 11, 18, 19). During the period between the 8 th and 5th century BC, a stone, soil, and wood structure was built along the edges of the hilltop. This construction was destroyed by fire several times during the said period and was rebuilt after each event of destruction (figs. 9-11). The very first reinforcements of the sloping edge on the hilltop included wooden fencing, supported by a 0.5 -metre high wall of fieldstones and sand (Context 1). After the first fire, a more durable reinforcement was constructed of soil and oak timbers (Context 2). However, it burned down as well and had to be reconstructed yet again. During the raising of the rampart, a ditch was being formed simultaneously on its outer side, in the place of the present ditch. Calibrated radiocarbon dates of the wooden reinforcements span over 300 years and fall within the Hallstatt radiocarbon calibration plateau (Table 2, Fig. 13). The burnt timbers were found intact; therefore, it is thought that reconstructions of the rampart were carried out soon after every event of destruction.

During the turn from the Subboreal to the Subatlantic (around $850 \mathrm{cal} \mathrm{BC}$ ), the climate began to shift, thus pushing people to relocate to higher elevations. Structural features of Kupiškis hillfort, its burning and subsequent rebuilding, would suggest that people intended to stay in this particular location persistently (or to occupy it repeatedly). On the other hand, it is difficult to judge whether the few traces of evidence of everyday life (such as pottery sherds, animal bones, and single grains of cereals, lentils and barley) can confirm that this was really what the people were striving for. The doubts were furthered by the fact that no artefacts made of bone, antler, or stone (inseparable attributes of the Brushed Pottery culture of north-east Lithuania), have been discovered.

During the 2nd and 3rd century, hillforts were being abandoned. Consequently, pottery of the 1st millennium $\mathrm{AD}$ is seldom found on the hilltops. In Kupiškis, this phase was illustrated by finds from Context 5, which included burnished ware and pottery with a grained surface (found as prevailing types), pottery with a smoothed or brushed surface (recovered in lesser quantities), and several sherds of rough-surface pottery and wheel-thrown pottery of the historical periods (medieval or post-medieval). Sediments containing such artefacts could have accumulated in a relatively short period, albeit in later times than the said objects. All in all, it should be noted that archaeological data that was recovered from Context 5 can only be perceived as general information. Even though it revealed that some activity did take place on the hillfort at the turn of the millennium, no traces of a cultural layer of the said period were discovered.

The hill functioned as a space for certain activities for a long time, although not continuously and it probably was not inhabited. Some material traces of activity were also discovered for the period between the middle and the second half of the 1st millennium, which is seen as evidence that the hillfort was not abandoned during this phase. Furthermore, these discoveries follow the general development model of Selonian hillforts. The charcoal covering this horizon was dated through AMS to the 5th-6th century, which showed that the hillfort was reinforced but burned down.

While the hillfort might have been abandoned for some time after the fire of the middle of the 1st 
millennium, in the second half of the 1st millennium fortifications were again reconstructed, followed by yet another fire in the period between the end of the 8th and the 10th century. Earlier cultural sediments were used during the fourth reconstruction of the rampart (Context 4). The fact that no artefacts dated to the second half of the 1st millennium were found indicates that the hillfort was not inhabited, which fits the general development model of Selonian hillforts. Lastly, it is not certain whether the burnt reinforcements of the fourth quarter of the 8th and the 10th century mark the end just for the fortification constructions or the entire community who lived nearby the hillfort.

The period between the 8 th and the 10th century is the final phase of the hillfort's existence during the prehistory. Since no traces dating to the beginning of the 2 nd millennium were discovered, the role of this hillfort in relation to the settlement pattern within the region has not been considered. Fortifications that are visible to this day were more typical to the Middle Ages, while the results of the conducted investigations present the hillfort's existence as spanning over different time periods. As such, this is not a mistake in interpretation, as the outer fortifications have not been investigated as of yet and it has not been determined during which period was the hill enclosed by the ditch (visible to this day) and the ring of a rampart. Finds of the historical times (two coins of the 17th century, a whetstone, several fragments of wheel-thrown pottery, and possibly bones of wild animals such as deer) were not directly related to the life on the hillfort. Rather, they were revealing of a role that it played in the life of the nearby manor and the growing town's community.

\section{LIST OF ILLUSTRATIONS}

Fig. 1. Situation plan showing the hillfort of Kupiškis (Aukštupenai) (1), Pajuodupe Manor (2) and Kupiškis town (3). The plan is based on a terrain model composed of LIDAR data and a Imperial
German military topographic map (scale 1: 25 000) issued on the basisof the 1882-1907 imperial Russian instrumental topographical photograph (scale 1:12 000). Drawing by A. Simniškyte.

Fig. 2. Hillfort of Kupiškis (Aukštupenai) as seen from the east. Photo by A. Simniškytè.

Fig. 3. Plan of the hillfort and cross-sections of ramparts (Кживицкий 1909, pис.8).

Fig. 4. Soil columns extracted by using two types of augers. Photo by A. Simniškytè.

Fig. 5. Locations of boreholes (1), location of the trench (2), thickness of the cultural layer and its extent across the hilltop as shown by the results of borehole samples. Drawing by A. Simniškyte.

Fig. 6. A magnetogram of geophysical survey based on data presented by R. Vengalis (2017). 1 locations of boreholes; 2 - location of the trench; 3 - potentially archaeological anomalies. Drawing by A. Simniškytè.

Fig. 7. Relationship between profiles received from the GPR (bottom image), the current surface (black lines) and the paleo relief (brown colour). Based on data presented by R. Vengalis (2017). Drawing by A. Simniškytè.

Fig. 8. Vertical variation in soil property values (MS, $P$ and OM) obtained from borehole cores nos. 75, 89 and 108. Compiled by A. Simniškytè.

Fig. 9. Eastern and southern walls of the trench in the location of the rampart (white numbers mark contexts 1 to 6 that were mentioned in the text). Photo by A. Simniškyte.

Fig. 10. Cross-section of trench walls and distribution of AMS ${ }^{14} \mathrm{C}$ dates. A - samples, dated to the period between the 8 th and 5 th century BC; $\mathrm{B}$ samples, dated to the period between the 5 th and 6 th century AD; C-samples, dated to the period between the 8 th and 10th century AD. Conventional marks: 1 - stones; 2 - greyish-yellow sand; 3 - sandy soil; 4 cemented silty soil; 5 - buried surfaces; 6 - weathered silty soil; 7 - a layer of charcoal; 8 - blackish sand; 9 - greyish sandy soil; 10 - grey sand; 11 - loam; 
12 - loam with rocks; 13 - topsoil. (Red numbers mark contexts 1 to 6 that were mentioned in the text). Drawing by A. Simniškytè.

Fig. 11. Plan of the trench and distribution of AMS ${ }^{14} \mathrm{C}$ dates: A- Context 1: reinforcements in the depth of 140-170 cm, in the location of a rampart; B-Context 2: reinforcements in the depth of 110$140 \mathrm{~cm}$, in the location of a rampart; C- contexts 3 and 4: reinforcements in the depth of $30-110 \mathrm{~cm}$, in the location of a rampart; $\mathrm{D}$ - cross-section of sunken features. Conventional marks: 1 and 2 - stones (from 30 to $170 \mathrm{~cm}$, from light to dark); 3 - charred wood; 4 - contours of timber (?); 5 - probable post holes and locations of their section; 6 - probable archaeological features (of unclear function). (For the description of AMS ${ }^{14} \mathrm{C}$ symbol meanings, please see Fig. 10). Drawing by A. Simniškytè.

Fig. 12. Feature no. 1. Photo by A. Simniškytè.

Fig. 13. Diagram of calibrated AMS ${ }^{14} \mathrm{C}$ dates. Compiled by A. Simniškytè.

Fig. 14. Probable post holes in the central part of the trench and traces of a cultural layer accumulated between the rampart and surface of the sloping hilltop. Photo by A. Simniškytè.

Fig. 15. Remains of a burnt wooden structure (as seen from the north-west). Further back, traces of a burnt stake construction (Context 1) can be seen; closer to the front- burnt timbers are visible (Context 2). Photo by A. Simniškytè.

Fig. 16. Part of the cross-section of the trench's southern wall. Arrows mark the layer of charcoal above Context 3. Photo by A. Simniškytè.

Fig. 17. General view of the trench at a depth of 1 metre. Dark coloured sediments (Context 5) that have accumulated between the rampart and surface of the sloping hilltop as seen from the north. Feature no. 1 is visible in the western end of the trench. Photo by A. Simniškytè.

Fig. 18. Distribution of pottery types across the contexts $(\mathrm{K})$ that were mentioned in the text: A- by weight (g), B- by sherd count. Compiled by A. Simniškytè.

Fig. 19. Pottery of different periods: $1-5$ sherds with a brushed surface; 6 - sherd with a rough surface; 7- rim adorned with imprints of a geometric ornament; 8- sherd with elements of pinched decoration; 9-11 wheel-thrown pottery with glaze. (In the brackets, find number is shown as applied in the field). Photo by A. Simniškytè.

Fig. 20. Hand-built pottery with fine-grained (1) and burnished (2-9) surface (In the brackets, find number is shown as applied in the field). Photo by A. Simniškyté.

Fig. 21. Finds dated to the historical times: $1-$ a poor-quality silver Riga schilling, the year 1615, (Sigismund III Vasa); 2 - a poor-quality silver Riga schilling (Gustav II Adolf), 1621-1634; 3 - a lead seal; 4 - a whetstone; 5 - a metal button from a German uniform. Photo by A. Simniškyte

Fig. 22. Animal species identified by G. Piličiauskienè (2018) from zooarchaeological material found in contexts $(\mathrm{K})$ mentioned in the text. Compiled by A. Simniškytè.

Table 1. Distribution of pottery types across the contexts $(\mathrm{K})$ that were mentioned in the text: by units, by weight $(\mathrm{g})$, and degree of fragmentation, average $(\bar{x})$ and median ( $\tilde{x})$. Compiled by A. Simnišskyte.

Table 2. Results of AMS ${ }^{14} \mathrm{C}$ dating and types of wood (as identified by K. Peseckas (2018). Compiled by A. Simniškytè. 